\title{
Impact of prior therapies on everolimus activity: an exploratory analysis of RADIANT-4
}

\author{
This article was published in the following Dove Press journal: \\ OncoTargets and Therapy \\ 16 October 2017 \\ Number of times this article has been viewed
}

\author{
Roberto Buzzoni,' Carlo \\ Carnaghi, ${ }^{2}$ Jonathan \\ Strosberg, ${ }^{3}$ Nicola Fazio, ${ }^{4}$ \\ Simron Singh, ${ }^{5}$ Fabian \\ Herbst, ${ }^{6}$ Antonia Ridolfi, ${ }^{7}$ \\ Marianne E Pavel, ${ }^{8}$ Edward \\ M Wolin, ${ }^{9}$ Juan W Valle, ${ }^{10}$ \\ Do-Youn Oh, "' James C \\ Yao, ${ }^{12}$ Rodney Pommier ${ }^{13}$ \\ 'IRCCS Foundation, National Institute \\ of Tumors, Milan, Italy; ${ }^{2}$ Humanitas \\ Clinical and Research Center, \\ Rozzano, Italy; ${ }^{3}$ Moffitt Cancer \\ Center, Tampa, FL, USA; ${ }^{4}$ European \\ Institute of Oncology, Milan, Italy; \\ ${ }^{5}$ Sunnybrook Health Sciences Centre, \\ Toronto, ON, Canada; ${ }^{6}$ Novartis \\ AG, Basel, Switzerland; ${ }^{7}$ Novartis \\ Pharma S.A.S., Rueil-Malmaison, \\ France; ${ }^{8}$ Medizinische Klinik I, \\ Friedrich-Alexander-Universität \\ Erlangen-Nürnberg, Erlangen, \\ Germany; ${ }^{M}$ Montefiore Einstein \\ Center for Cancer Care, Bronx, NY, \\ USA; ${ }^{10}$ Institute of Cancer Sciences, \\ University of Manchester, The Christie \\ Hospital, Manchester, UK; "Seoul \\ National University Hospital, Seoul, \\ Republic of Korea; ${ }^{2}$ University of \\ Texas M.D. Anderson Cancer Center, \\ Houston, TX, USA; ${ }^{3}$ Oregon Health \& \\ Science University, Portland, OR, USA
}

Correspondence: Roberto Buzzoni Direttore S.C. Day Hospital e Terapia Ambulatoriale Oncologica, Fondazione IRCCS, Istituto Nazionale Tumori, via Venezian I, 20133, Milan, Italy

Tel +02 23904447

Fax +02 23903992

Email roberto.buzzoni@

istitutotumori.mi.it
Background: Recently, everolimus was shown to improve median progression-free survival (PFS) by 7.1 months in patients with advanced, progressive, well-differentiated, nonfunctional neuroendocrine tumors (NET) of lung or gastrointestinal (GI) tract compared with placebo (HR, $0.48 ; 95 \%$ CI, $0.35-0.67 ; P<0.00001$ ) in the Phase III, RADIANT-4 study. This post hoc analysis evaluates the impact of prior therapies (somatostatin analogs [SSA], chemotherapy, and radiotherapy) on everolimus activity.

Trial registration: ClinicalTrials.gov identifier: NCT01524783.

Patients and methods: Patients were randomized (2:1) to everolimus $10 \mathrm{mg} /$ day or placebo, both with best supportive care. Subgroups of patients who received prior SSA, chemotherapy, or radiotherapy (including peptide receptor radionuclide therapy) were analyzed and reported.

Results: A total of 302 patients were enrolled, of whom, 163 (54\%) had any prior SSA use (mostly for tumor control), 77 (25\%) received chemotherapy, and 63 (21\%) were previously exposed to radiotherapy. Patients who received everolimus had longer median PFS compared with placebo, regardless of previous SSA (with SSA: 11.1 vs 4.5 months [HR, $0.56\{95 \%$ CI, 0.37-0.85\}]; without SSA: 9.5 vs 3.7 months [0.57 $\{0.36-0.89\}]$ ), chemotherapy (with chemotherapy: 9.2 vs 2.1 months [0.35 $\{0.19-0.64\}]$; without chemotherapy: 11.2 vs 5.4 months [0.60 $\{0.42-0.86\}]$ ), or radiotherapy (with radiotherapy: 9.2 vs 3.0 months [0.47 $\{0.24-0.94\}]$; without radiotherapy: 11 vs 5.1 months $[0.59\{0.42-0.83\}])$ exposure. The most frequent drug-related adverse events included stomatitis (59\%-65\%), fatigue (27\%-35\%), and diarrhea (24\%-34\%) among the subgroups.

Conclusion: These results suggest that everolimus improves PFS in patients with advanced, progressive lung or GI NET, regardless of prior therapies. Safety findings were consistent with the known safety profile of everolimus in NET.

Keywords: neuroendocrine tumors, progression-free survival, somatostatin analogs, chemotherapy, PRRT

\section{Plain language summary}

As most patients with advanced, progressive neuroendocrine tumors will experience disease progression at some point during their treatment, an ongoing consideration of significant importance is the optimal sequence of treatment, which currently remains unknown. This post hoc analysis of the Phase III, randomized, placebo-controlled, RADIANT-4 study demonstrates that treatment with everolimus improved outcomes regardless of the use of prior therapies and suggests the potential for its use in both treatment-naive and previously treated patients with advanced, welldifferentiated, progressive, nonfunctional neuroendocrine tumors of lung or gastrointestinal origin. In addition, safety of everolimus was generally consistent regardless of use of prior therapies.

\section{Introduction}

Neuroendocrine tumors (NET) are rare and a diverse group of neoplasms arising from neuroendocrine cells throughout the body, with the gastroenteropancreatic (c)
hereby accept the Terms. Non-commercial uses of the work are permitted without any further permission from Dove Medical Press Limited, provided the work is properly attributed. For permission

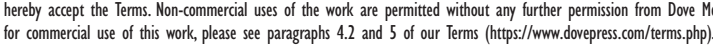


(GEP; 57\%) tract and the lungs $(\sim 27 \%)$ being the most common sites. ${ }^{1,2}$ Although considered rare, the annual incidence of NET has steadily increased over the past 4 decades from 1.09 per 100,000 in 1973 to 6.98 per 100,000 in $2012 .^{2,3}$ NET are termed "functional" if they are associated with classical clinical symptoms (eg, carcinoid syndrome) due to hormonal hypersecretion, whereas those that do not exhibit symptoms are labeled as "nonfunctional" NET. ${ }^{4}$ The majority of NET originating from the gastrointestinal (GI) tract and lung are nonfunctional. According to the Surveillance, Epidemiology, and End Results program, approximately half of patients have metastatic disease at the time of diagnosis, and $65 \%$ will die within 5 years of diagnosis. ${ }^{2}$ The clinical course, management, and prognosis may vary widely and depend on multiple factors. These include disease-related factors, for example, primary tumor sites, histologic classification, resectability of the tumor, presence of metastatic disease, and presence of clinical symptoms and patient-related factors, for example, treatment goals, comorbidities, and treatment access. All of these factors should be taken into consideration when preparing a treatment plan for individual patients. ${ }^{5}$

The treatment of inoperable, advanced NET is challenging due to limited therapeutic options. Although international guidelines have suggested potential treatment algorithms, the treatment of metastatic NET can vary widely based on patient factors as well as treatment centers due to lack of consensus for a single standard of care approach. Very few randomized controlled trials have been conducted in NET owing to the rarity of these tumors, and hence, the evidence supporting some treatment options is considered much weaker than for more common malignancies. ${ }^{6}$ Patients with progressive NET of lung or GI tract have traditionally relied on somatostatin analogs (SSA), chemotherapy, and radiotherapy despite limited data from well-controlled, randomized clinical trials. SSA, such as octreotide and lanreotide, are the standard of care for symptom management in patients with functional NET. ${ }^{7,8}$ Furthermore, the antiproliferative effects of SSA have been confirmed in more recent prospective Phase III trials in patients with well-differentiated GEP-NET.., 10 Chemotherapy remained the only recommended therapeutic option in the treatment of advanced pancreatic NET (pNET) until the availability of novel targeted agents. Response rates reported from various retrospective studies of chemotherapy ranged from $25 \%$ to $42 \% .{ }^{11-13}$ The benefit in response rate with chemotherapy did not translate to prolongation of PFS compared with historical controls, although such comparison is difficult in view of heterogeneity between studies and patient populations. In addition, significant cumulative toxicities associated with systemic chemotherapy use limit its long-term usage. Peptide receptor radionuclide therapy (PRRT) is an emerging treatment modality and could be a promising new treatment option for advanced, progressive somatostatin receptor-positive midgut NET. ${ }^{14}$ However, its use remains investigational and limited information is available on long-term safety of PRRT.

In the past 6 years, everolimus (Afinitor, Novartis Pharmaceuticals Corporation [East Hanover, NJ, USA]; both as a single agent and in combination with long-acting octreotide) has demonstrated activity in the treatment of a broad spectrum of NET subtypes in various Phase II and III studies. ${ }^{15-20}$ In the recent Phase III, RADIANT-4 study, treatment with everolimus improved median progression-free survival (PFS) by 7.1 months and resulted in a $52 \%$ reduction in risk for disease progression or death (hazard ratio [HR], 0.48; 95\% confidence interval $[\mathrm{CI}], 0.35-0.67 ; P<0.00001)$ compared with placebo in patients with advanced, nonfunctional, progressive lung or GI NET. ${ }^{21}$ Everolimus showed consistent treatment benefits across all subgroups analyzed in the RADIANT-4 study; however, the impact of prior therapies on the activity of everolimus in this population is not known. This post hoc exploratory analysis was aimed to explore the effects of prior therapies (SSA, chemotherapy, and radiotherapy) on PFS in patients enrolled in the Phase III RADIANT-4 study and identify any impact of specific treatment sequences on outcomes of everolimus therapy for the treatment of individual patients with advanced NET.

\section{Patients and methods Study design}

The RADIANT-4 trial was a prospective, double-blind, randomized, parallel-group, placebo-controlled, international, multicenter, Phase III study (ClinicalTrials.gov number NCT01524783). The detailed study design has been reported previously. ${ }^{21}$ Patients were randomly assigned, in a 2:1 ratio, to receive everolimus $10 \mathrm{mg} /$ day or placebo in combination with best supportive care. Treatment was continued until documented radiologic disease progression, development of an unacceptable adverse event (AE), initiation of new cancer therapy, or withdrawal of consent. Patients were prospectively stratified according to status with respect to prior SSA treatment (defined as continuous SSA for $\geq 12$ weeks; receipt vs no receipt), tumor origin (based on prognostic level, grouped into 2 strata: 1) stratum A [better prognosis]: appendix, cecum, jejunum, ileum, duodenum, or NET of unknown primary; 2) stratum B [worse prognosis]: lung, stomach, colon [other than cecum] or rectum), and World Health Organization (WHO) performance status (0 vs 1$)$ at baseline. Crossover was not permitted 
to open-label everolimus prior to primary PFS analysis if patients in placebo arm experienced disease progression.

In the current post hoc exploratory analysis of the RADIANT-4 study, patients were classified into the following subgroups based on whether they had received previous treatments with SSA, chemotherapy, or radiotherapy (including PRRT) at any time before study enrollment: prior SSA, no prior SSA, prior chemotherapy, no prior chemotherapy, prior radiotherapy, and no prior radiotherapy. The efficacy and safety of everolimus compared with placebo were assessed in each of these subgroups. Additional subgroups analyzed were the following: 1) everolimus as first-line treatment, which includes patients with no prior medical treatments (eg, SSA, chemotherapy, hormonal therapy, radiotherapy, targeted therapy) with or without prior surgery excluding other local surgeries (eg, biopsy, radiofrequency ablation, transarterial embolization, selective internal radiotherapy, percutaneous ethanol injection, and cryoablation); 2) everolimus as second-line treatment after prior SSA includes patients with only prior SSA and no other medical treatments (eg, chemotherapy, hormonal therapy, radiotherapy, targeted therapy) with or without prior surgery excluding other local surgeries.

\section{Ethics}

The protocol was reviewed and approved by an independent ethics committee or institutional review board (IRB) at each participating center and all patients gave written informed consent prior to participation. The list of each approving ethics committee and IRB is provided in Table S1. The study was conducted in accordance with Good Clinical Practice, the principles outlined in the Declaration of Helsinki, and local regulations.

\section{Patient population}

Adult patients (18 years or older) with histologically confirmed well-differentiated (grade 1 or 2 according to the 2010 WHO classification), ${ }^{22}$ advanced, nonfunctional lung or GI NET and radiological documentation of disease progression within 6 months before randomization were eligible for inclusion. Additional key inclusion criteria included the presence of measurable disease according to Response Evaluation Criteria In Solid Tumors (RECIST) criteria ${ }^{23} 1.0$ using multiphase computed tomography or magnetic resonance imaging for radiological assessment, WHO performance status of 1 or lower, and adequate bone marrow, renal, and hepatic function. Patients previously treated with SSA, interferon, one prior line of chemotherapy, and/or radiation therapy (including PRRT) were eligible for inclusion if disease progression was documented during or after their last treatment. It was also necessary for patients to have discontinued antineoplastic therapy for $\geq 4$ weeks ( 6 months if PRRT) before randomization.

Patients were excluded if they had a history of or presented with carcinoid syndrome, poorly differentiated histology, or pNET. Concomitant SSA were permitted if the patients developed symptoms of carcinoid syndrome, which could not be managed by standard therapy (eg, loparamide). The change in functional status and the use of concomitant medications was documented. Patients who received $>1$ line of chemotherapy; prior therapy with mammalian target of rapamycin (mTOR) inhibitors (sirolimus, temsirolimus, or everolimus); hepatic intra-arterial embolization within 6 months, or cryoablation or radiofrequency ablation of hepatic metastases within 2 months of randomization; or chronic treatment with corticosteroids or other immunosuppressive agents were also excluded.

\section{Statistical analyses}

In this post hoc exploratory analysis, efficacy assessments were conducted on the full analysis population, which was composed of all randomly assigned patients. All patients who received $\geq 1$ dose of the study drug and who had $\geq 1$ postbaseline safety evaluation were included in the safety population.

The median PFS as well as the 25th and 75th quartile were estimated using the Kaplan-Meier method and presented along with 95\% CIs. HRs and corresponding 95\% CIs were calculated using unstratified Cox proportional hazards model.

\section{Results}

\section{Patient demographics and disposition}

In the RADIANT-4 trial, 302 patients with advanced NET were randomly assigned to everolimus $10 \mathrm{mg} /$ day $(\mathrm{n}=205)$ or placebo $(\mathrm{n}=97) .{ }^{21}$ Both arms were comparable with respect to any prior SSA therapy $(53 \%[\mathrm{n}=109]$ of patients receiving everolimus vs $56 \%$ [ $\mathrm{n}=54]$ receiving placebo; mostly for tumor control), chemotherapy ( $26 \%[\mathrm{n}=54]$ vs $24 \%$ [n=23]), and radiotherapy $(21 \%[\mathrm{n}=44]$ vs $20 \%[\mathrm{n}=19])$. Prior radiotherapy arm also included PRRT $(n=19 ; 15$ patients in everolimus and 4 in placebo arm). A total of 5 patients (4 in everolimus and 1 in placebo arm) received concomitant SSA. A change in functional status was observed in 17 patients (10 in everolimus arm and 7 in placebo arm).

Baseline demographics and clinical characteristics of patients in different subgroups were similar (Table 1). Overall, the primary tumor sites were GI (58\% of patients; including ileum, rectum, jejunum, stomach, colon, 


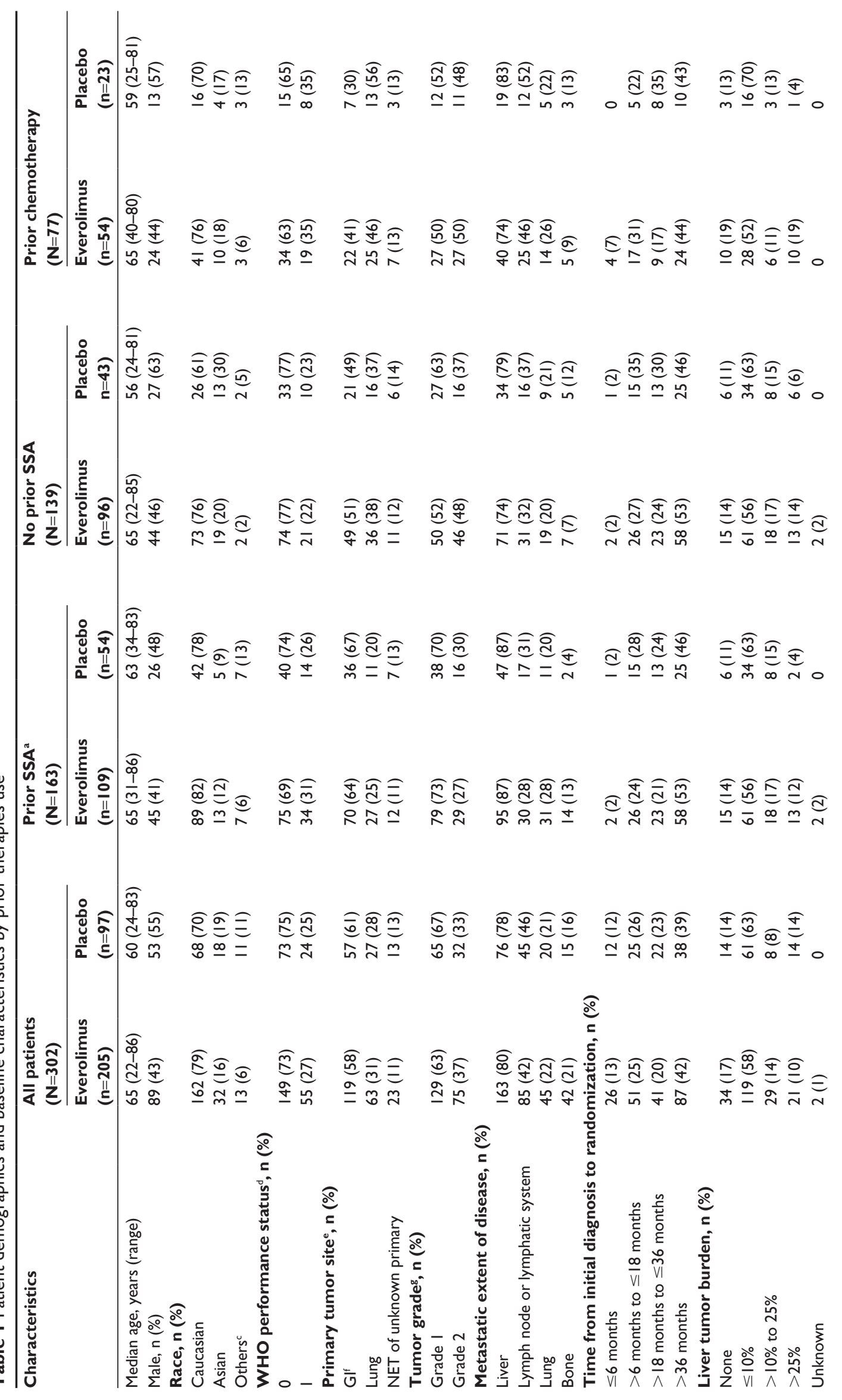




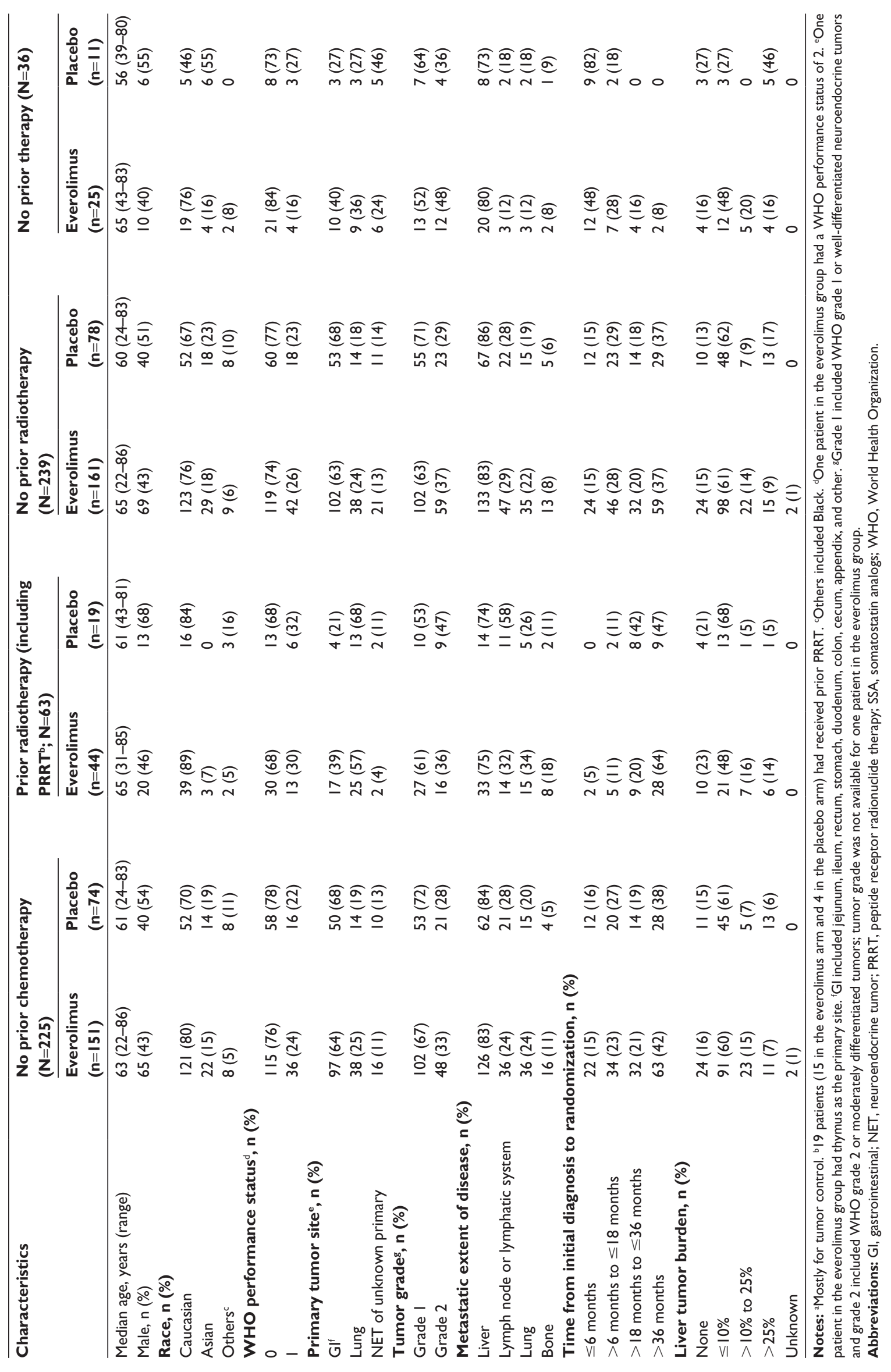


Table 2 Prior SSA exposure by study treatment (full analysis set)

\begin{tabular}{|c|c|c|c|}
\hline SSA exposure & Everolimus $(\mathrm{n}=109)$ & Placebo $(n=54)$ & All patients $(\mathrm{N}=163)$ \\
\hline $\begin{array}{l}\text { Median (range) duration of } \\
\text { prior SSA exposure, months }\end{array}$ & $15.90(<0.1-103.5)$ & $14.87(<0.1-77.3)$ & $14.95(<0.1-103.5)$ \\
\hline \multicolumn{4}{|c|}{ Duration of prior SSA exposure, $n$ (\%) } \\
\hline$<6$ months $^{\mathrm{a}}$ & $25(23)$ & $15(28)$ & $40(25)$ \\
\hline 6 months to $<2$ years & $46(42)$ & $21(39)$ & $67(4 I)$ \\
\hline 2 years to $<5$ years & $27(25)$ & $13(24)$ & $40(25)$ \\
\hline$\geq 5$ years & II (I0) & $5(9)$ & $16(10)$ \\
\hline \multicolumn{4}{|c|}{ Time since last prior exposure to SSA, $\mathbf{n}(\%)$} \\
\hline Ongoing & 0 & 0 & 0 \\
\hline$<4$ weeks & 0 & 0 & 0 \\
\hline 4 weeks to $<8$ weeks & $43(39)$ & $25(46)$ & $68(42)$ \\
\hline 8 weeks to $<24$ weeks & $43(39)$ & $19(35)$ & $62(38)$ \\
\hline 24 weeks to $<2$ years & $16(15)$ & $6(\mathrm{II})$ & $22(14)$ \\
\hline 2 years to $<5$ years & $6(6)$ & $3(6)$ & $9(6)$ \\
\hline$\geq 5$ years & $I(I)$ & I (2) & $2(1)$ \\
\hline
\end{tabular}

Note: aSeven patients ( 4 in the everolimus and 3 in the placebo arm) had SSA exposure of $<2$ weeks.

Abbreviation: SSA, somatostatin analogs.

duodenum, cecum, appendix, and other sites identified by investigators as GI), lung (31\%), and NET of unknown primary (11\%). The GI subgroup was further categorized into midgut NET (38\% of patients; included primary tumors originating in the duodenum, small intestine [ileum and jejunum], cecum, appendix, and other origins identified by investigators as GI, mostly from small intestine) and nonmidgut NET ( $20 \%$ of patients; primary tumors originating from stomach, colon, and rectum). More than $60 \%$ of patients had well-differentiated (grade 1) disease, $>70 \%$ had WHO performance status of very good (ie, zero [0]), and the majority (80\%) had liver involvement.

A total of 163 patients received prior SSA for any duration (most common SSA received were long-acting octreotide in 126 patients and lanreotide autogel in 23 patients). The median duration of prior exposure to SSA in all patients was 15.0 months (range, $<0.1-103.5$ ) and was similar in both treatment arms (Table 2). A total of 105 patients (everolimus arm [n=69]; placebo arm [n=36]) had GI as the primary tumor site in the prior SSA subgroup. The median duration of exposure to prior SSA in patients with GI NET was 16.7 months (range, 0-103.5) and was longer in the everolimus arm (21.2 months) vs placebo (14.1 months). Only 25 patients (21 from everolimus arm and 4 in the placebo) in the prior SSA group were treatment-naive and did not receive any other antineoplastic treatments except SSA.

Of the 157 patients who received prior SSA continuously for at least 12 weeks, 96 had GI as primary tumor origin, which included 67 patients with midgut NET and 29 with non-midgut NET.

Eighty-five patients received everolimus as a first-line treatment, which include patients with no prior medical treatments (eg, SSA, chemotherapy, hormonal therapy, radiotherapy, targeted therapy) with or without prior surgery excluding other local surgeries. The number of patients who received everolimus as second-line treatment after prior SSA (only SSA with or without prior surgery excluding other local surgeries) was 78.

Table 3 Progression-free survival by central review (full analysis set)

\begin{tabular}{|c|c|c|c|c|}
\hline Median PFS, months $(95 \% \mathrm{CI})$ & No. of patients & Everolimus & Placebo & Hazard ratio $(95 \% \mathrm{Cl})$ \\
\hline All patients & 302 & $11.0(9.2-13.3)$ & $3.9(3.6-7.4)$ & $0.48(0.35-0.67)$ \\
\hline Prior SSA therapy & 163 & II.I (9.2-13.3) & $4.5(3.6-7.9)$ & $0.56(0.37-0.85)$ \\
\hline No prior SSA therapy & 139 & $9.5(8.2-16.7)$ & $3.7(2.4-8.1)$ & $0.57(0.36-0.89)$ \\
\hline Prior chemotherapy & 77 & $9.2(5.6-11.7)$ & $2.1(1.9-3.7)$ & $0.35(0.19-0.64)$ \\
\hline No prior chemotherapy & 225 & $11.2(9.2-16.6)$ & $5.4(3.7-9.0)$ & $0.60(0.42-0.86)$ \\
\hline Prior radiotherapy (including PRRT) ${ }^{\mathrm{a}}$ & 63 & $9.2(5.6-20.9)$ & $3.0(1.9-7.9)$ & $0.47(0.24-0.94)$ \\
\hline No prior radiotherapy & 239 & $11.0(9.2-13.9)$ & $5.1(3.6-8.1)$ & $0.59(0.42-0.83)$ \\
\hline No prior therapy & 36 & I3.6 (7.2-NE) & $5.6(1.7-18.5)$ & $0.48(0.19-1.18)$ \\
\hline
\end{tabular}

Note: anineteen patients ( 15 in the everolimus arm and 4 in the placebo arm) had received prior PRRT.

Abbreviations: $\mathrm{Cl}$, confidence interval; NE, not estimated; PFS, progression-free survival; PRRT, peptide receptor radionuclide therapy; SSA, somatostatin analogs. 


\section{Efficacy}

As summarized in Table 3 and shown in Figure 1, median PFS in everolimus arm was superior to placebo arm in all subgroups.

Among patients who received prior SSA for any duration, median PFS assessed by central review was 11.1 months (95\% CI, 9.2-13.3) in the everolimus arm vs 4.5 months (3.6-7.9) in the placebo arm. Everolimus was associated with

A
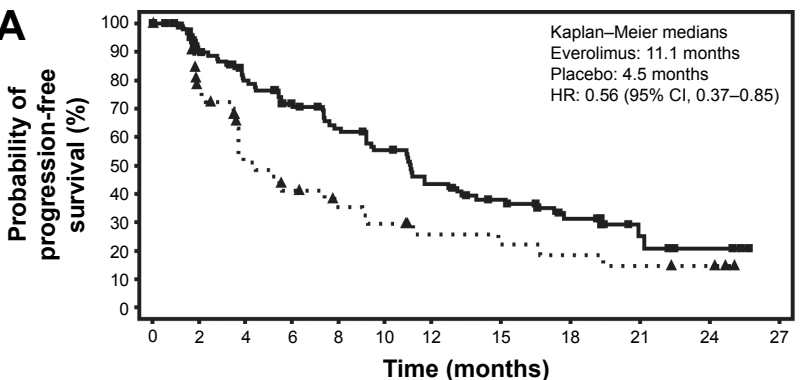

No. of patients still at risk

$\begin{array}{llllllllllllll}\text { Everolimus } & 109 & 85 & 71 & 60 & 50 & 43 & 33 & 26 & 17 & 6 & 3 & 0\end{array}$

$\begin{array}{lllllllllllll}\text { Placebo } & 54 & 36 & 21 & 16 & 12 & 10 & 7 & 6 & 5 & 4 & 3 & 0\end{array}$
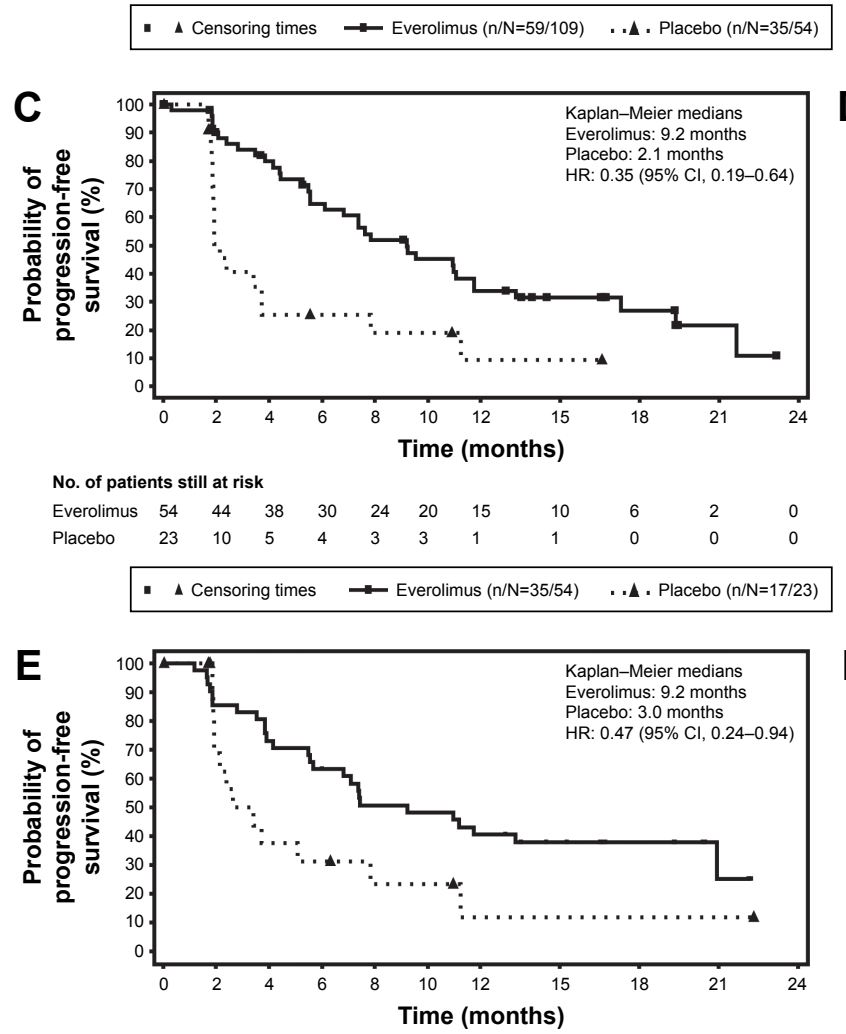

No. of patients still at risk

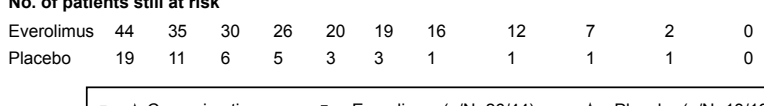

- $\Delta$ Censoring times $\rightarrow$ Everolimus $(\mathrm{n} / \mathrm{N}=26 / 44) \quad$... . Placebo $(\mathrm{n} / \mathrm{N}=13 / 19)$ a $44 \%$ reduction in the estimated risk of progression (HR, 0.56 ; 95\% CI, 0.37-0.85) in patients who received prior SSA. Among those patients who did not receive prior SSA, the median PFS in the everolimus arm was 9.5 months (95\% CI, 8.2-16.7) vs 3.7 months (2.4-8.1) in the placebo, with a $43 \%$ reduction in the estimated risk for progression (HR, 0.57; 95\% CI, 0.36-0.89).

Additionally, in the prior SSA subgroup, among patients who continuously received prior SSA for at least 12 weeks,

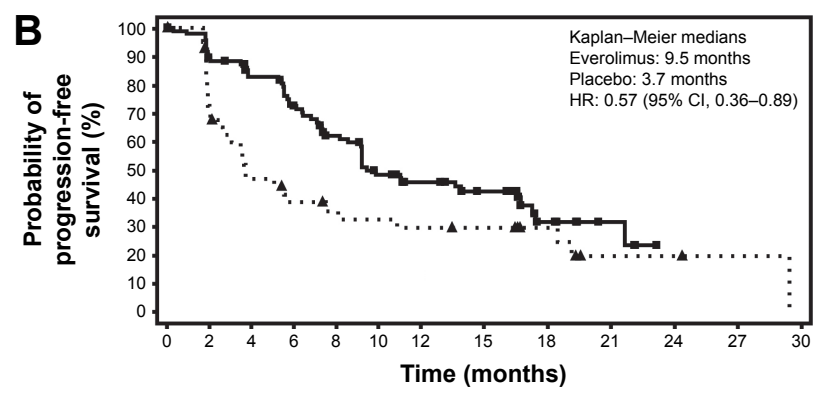

No. of patients still at risk

$\begin{array}{llllllllllllll}\text { Everolimus } & 96 & 83 & 74 & 64 & 51 & 38 & 32 & 26 & 9 & 4 & 0 & 0 & 0\end{array}$ $\begin{array}{llllllllllllll}\text { Placebo } & 43 & 29 & 18 & 14 & 12 & 11 & 10 & 9 & 6 & 2 & 2 & 1 & 0\end{array}$
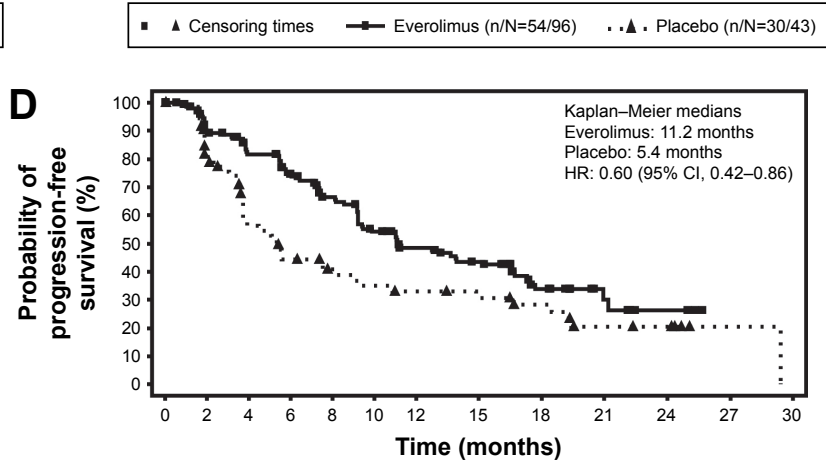

No. of patients still at risk

$\begin{array}{llllllllllllll}\text { Everolimus } & 151 & 124 & 107 & 94 & 77 & 61 & 50 & 42 & 20 & 8 & 3 & 0 & 0\end{array}$ $\begin{array}{llllllllllllll}\text { Placebo } & 74 & 55 & 34 & 26 & 21 & 18 & 16 & 14 & 11 & 6 & 5 & 1 & 0\end{array}$ - $\Delta$ Censoring times $\simeq$ Everolimus $(\mathrm{n} / \mathrm{N}=78 / 151) \quad$.. . . Placebo $(\mathrm{n} / \mathrm{N}=48 / 74)$

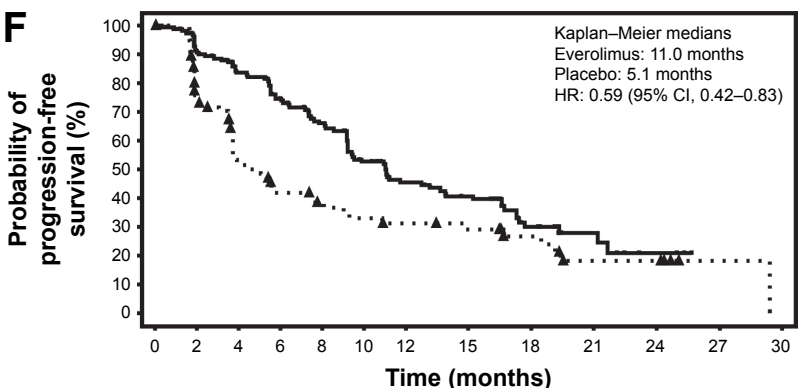

No. of patients still at risk

$\begin{array}{llllllllllllll}\text { Everolimus } & 161 & 133 & 115 & 98 & 81 & 62 & 49 & 40 & 19 & 8 & 3 & 0 & 0\end{array}$ $\begin{array}{llllllllllllll}\text { Placebo } & 78 & 54 & 33 & 25 & 21 & 18 & 16 & 14 & 10 & 5 & 5 & 1 & 0\end{array}$

- $\Delta$ Censoring times $\rightarrow$ Everolimus $(\mathrm{n} / \mathrm{N}=87 / 161) \quad \ldots$. . Placebo $(\mathrm{n} / \mathrm{N}=52 / 78)$

Figure I Progression-free survival by central review (full analysis set).

Notes: Kaplan-Meier curves are shown for progression-free survival as assessed by central radiology review for both treatment arms (everolimus and placebo) in the patients who received (A) prior SSA, (B) no prior SSA, (C) prior chemotherapy, (D) no prior chemotherapy, (E) prior radiotherapy, and (F) no prior radiotherapy. The HRs in subgroups are obtained from unstratified Cox proportional hazards model.

Abbreviations: $\mathrm{Cl}$, confidence interval; HR, hazard ratio; SSA, somatostatin analogs. 
median PFS (everolimus vs placebo; central review) was 11.2 months ( $95 \%$ CI, 9.2-17.3) vs 4.5 months (3.6-7.9) in the GI, 16.6 months $(9.2-21.2)$ vs 7.4 months $(3.7-16.7)$, in the midgut and 5.6 months (3.8-12.7) vs 1.9 months (1.6-4.5) in the non-midgut NET subgroups, respectively.

For patients who were previously treated with chemotherapy, the median PFS was 9.2 (95\% CI, 5.6-11.7) vs 2.1 months (1.9-3.7) with everolimus and placebo, respectively, with a $65 \%$ reduction in the estimated risk for progression (HR, 0.35; 95\% CI, 0.19-0.64) in the prior chemotherapy subgroup. In the chemo-naive patients, the median PFS for everolimus was 11.2 months $(95 \% \mathrm{CI}, 9.2-16.6)$ vs 5.4 months (3.7-9.0) for placebo, with a $40 \%$ reduction in the estimated risk for progression (HR, 0.60; 95\% CI, 0.42-0.86).

In the prior radiotherapy subgroup, centrally assessed median PFS was 9.2 months (95\% CI, 5.6-20.9) for everolimus vs 3.0 months (1.9-7.9) for placebo, corresponding to a $53 \%$ reduction in the estimated risk for progression (HR, 0.47; 95\% CI, 0.24-0.94). Among patients who did not receive prior radiotherapy, the median PFS also remained longer with everolimus vs placebo (11.0 months [95\% CI, 9.2-13.9] vs 5.1 months [3.6-8.1], respectively) resulting in a $41 \%$ reduction in the estimated risk for progression (HR, 0.59; 95\% CI, 0.42-0.83).

As reported in Table 4, everolimus as a first-line treatment was superior to placebo in treatment-naive patients who did not receive any prior medical treatments except surgery. Everolimus had substantially reduced the risk of disease progression or death ( $\mathrm{HR}=0.38$ [95\% CI, 0.21-0.71]) as a second-line treatment option in patients who received only prior SSA and no other antineoplastic therapies.

The response waterfall plot for patients who did and did not receive prior therapy is shown in Figure 2. Everolimus was associated with a higher disease control rate compared with placebo (ranged from $75 \%$ to $87 \%$ in everolimus arm vs $44 \%$ to $73 \%$ in placebo arm; Table 5).

\section{Safety}

As shown in Table 6, the incidence of AEs was not substantially influenced by the type of prior therapy, except for asthenia and dyspnea, which were substantially higher in patients with prior chemotherapy and prior radiotherapy, respectively. The safety profile of everolimus generally remained comparable in patients previously treated with PRRT ( $\mathrm{n}=15$ ) vs no prior PRRT, with the exception of a higher incidence of grade 3 to 4 neutropenia (13\% vs $1 \%$ ), noninfectious pneumonitis ( $7 \%$ vs $1 \%$ ), edema ( $7 \%$ vs $2 \%$ ), and thrombocytopenia ( $7 \%$ vs $1 \%$ ) observed in the everolimus

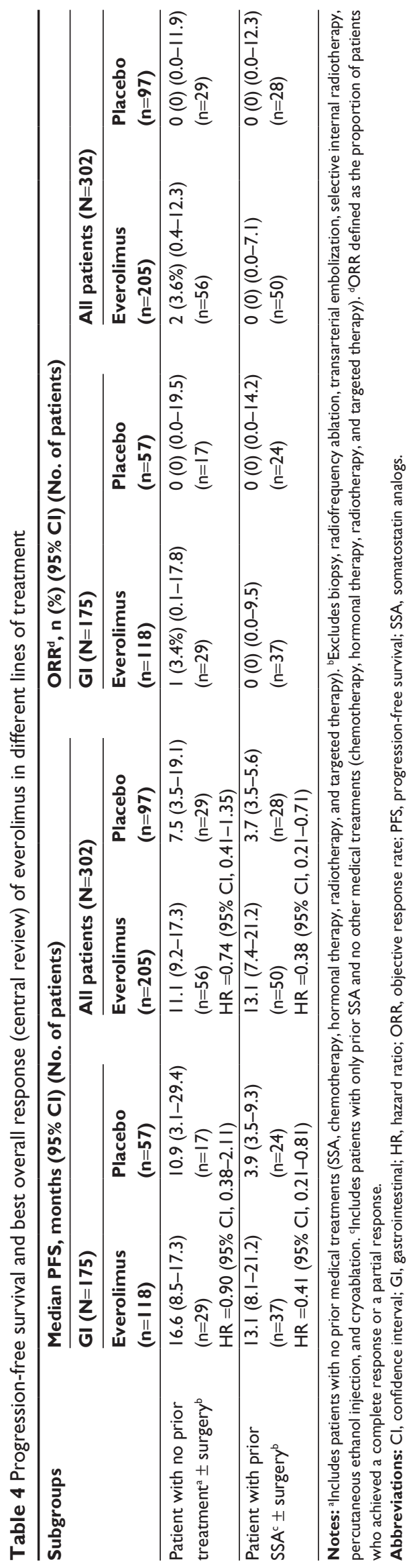



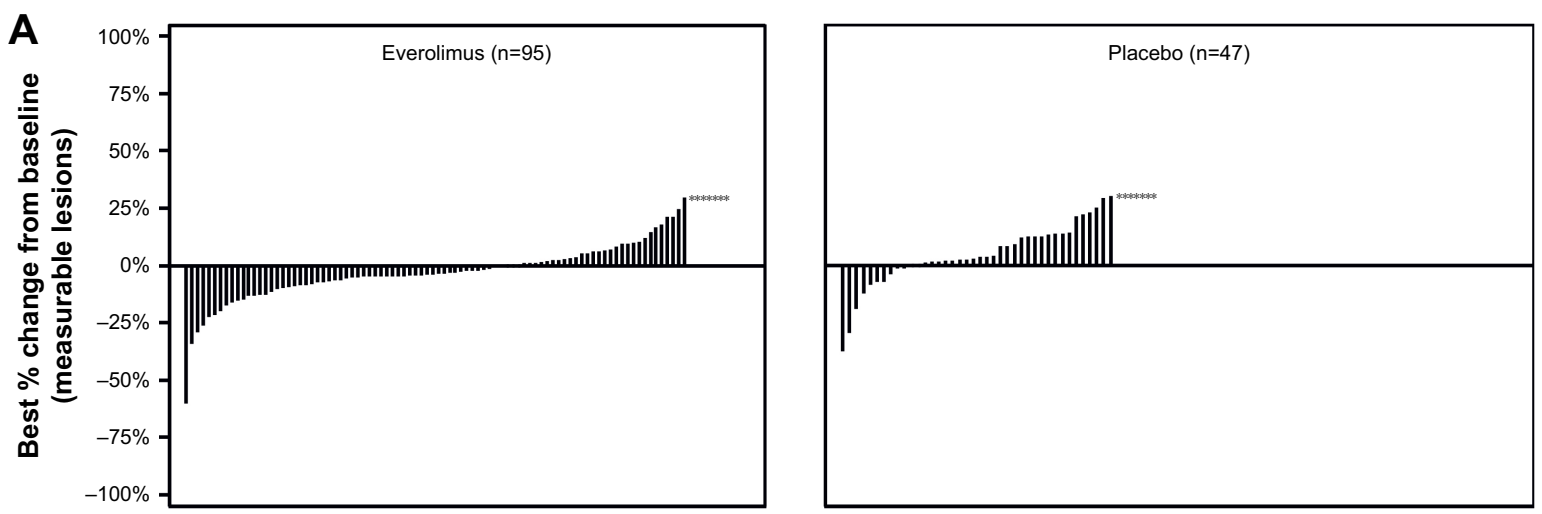

Decrease in best percentage change from baseline Increase/zero change in best percentage change from baseline

* indicates \% change in target lesion contradicted by overall lesion response $=$ PD

Everolimus Placebo

$60.0 \% \quad 21.3 \%$

$32.6 \% \quad 63.8 \%$

Patients for whom the best \% change in target lesions was not available and patients for whom the best $\%$ change in target lesions was contradicted by overall lesion response of unknown were excluded from the analysis, percentages above use $\mathrm{n}$ as denominator.
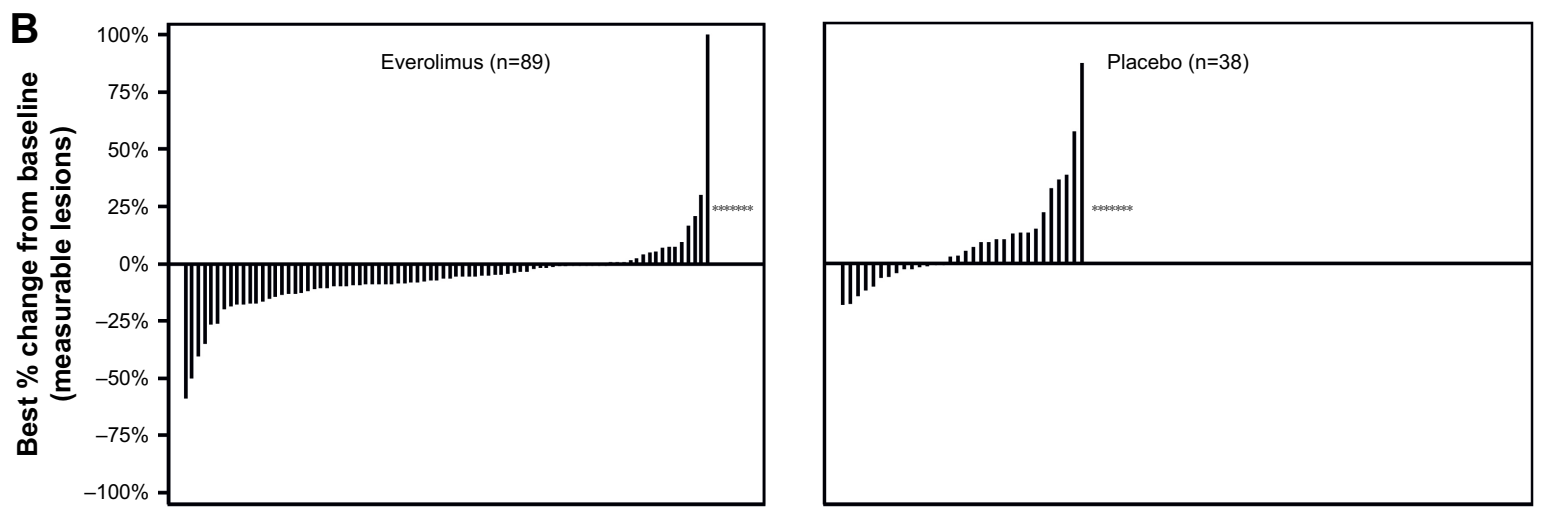

Decrease in best percentage change from baseline

Everolimus Placebo

Increase/zero change in best percentage change from baseline

$67.4 \%$

$31.6 \%$

$24.7 \% \quad 52.6 \%$

* indicates $\%$ change in target lesion contradicted by overall lesion response $=$ PD $7.9 \%$

$15.8 \%$

Patients for whom the best $\%$ change in target lesions was not available and patients for whom the best $\%$ change in target lesions was contradicted by

overall lesion response of unknown were excluded from the analysis, percentages above use $\mathrm{n}$ as denominator.
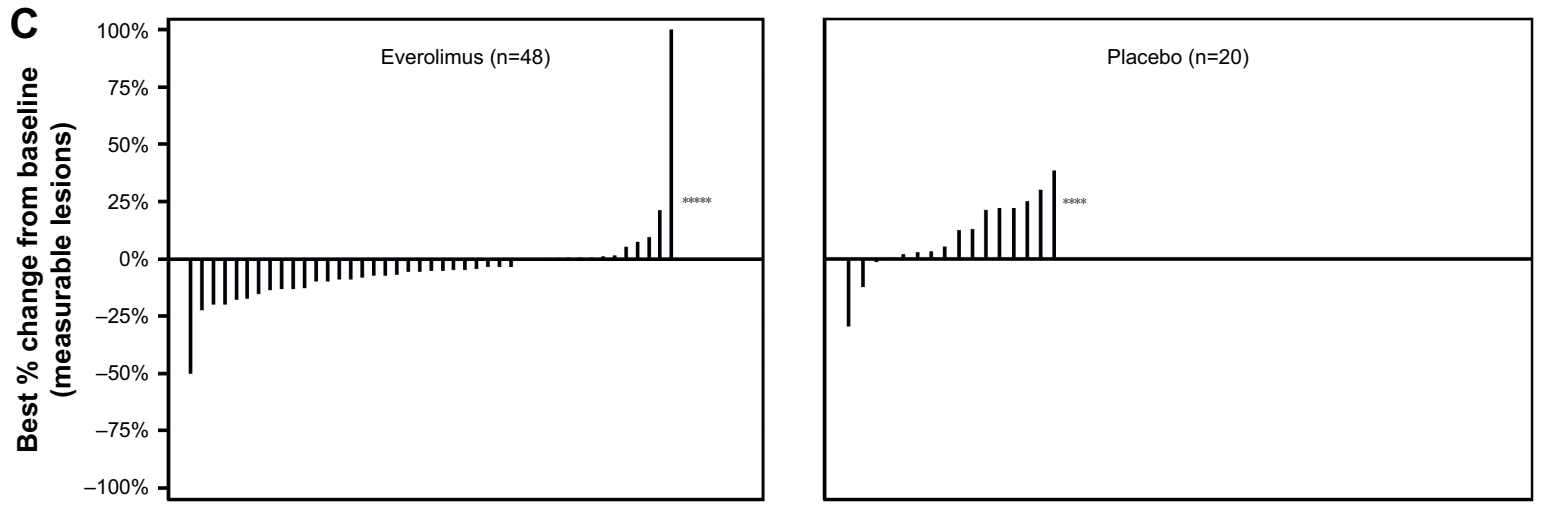

Decrease in best percentage change from baseline

Everolimus Placebo

$66.7 \% \quad 15.0 \%$

Increase/zero change in best percentage change from baseline

$15.0 \%$
$65.0 \%$

$*$ indicates $\%$ change in target lesion contradicted by overall lesion response $=$ PD $10.4 \% \quad 20.0 \%$

Patients for whom the best $\%$ change in target lesions was not available and patients for whom the best $\%$ change in target lesions was contradicted by overall lesion response of unknown were excluded from the analysis, percentages above use $\mathrm{n}$ as denominator.

Figure 2 (Continued) 

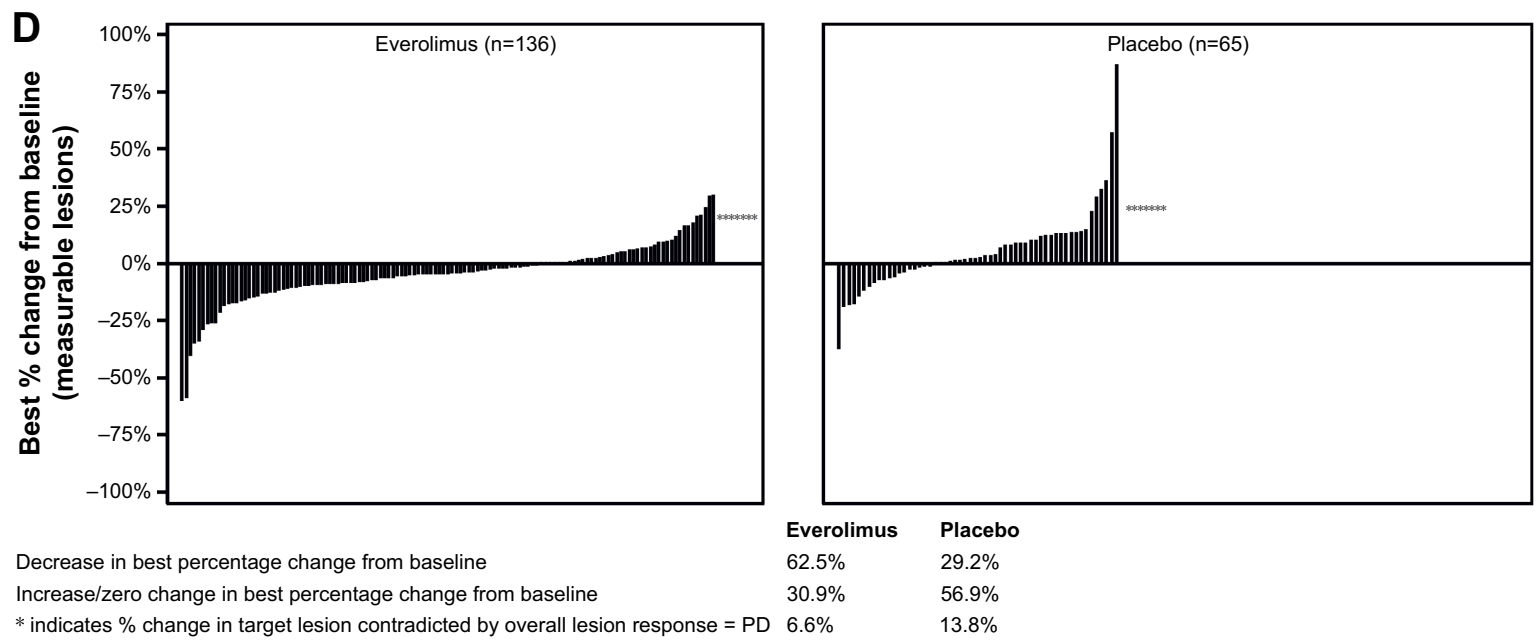

Decrease in best percentage change from baseline Increase/zero change in best percentage change from baseline

$*$ indicates $\%$ change in target lesion contradicted by overall lesion response $=$ PD $6.6 \%$

$13.8 \%$

Patients for whom the best \% change in target lesions was not available and patients for whom the best \% change in target lesions was contradicted by overall lesion response of unknown were excluded from the analysis, percentages above use $\mathrm{n}$ as denominator.

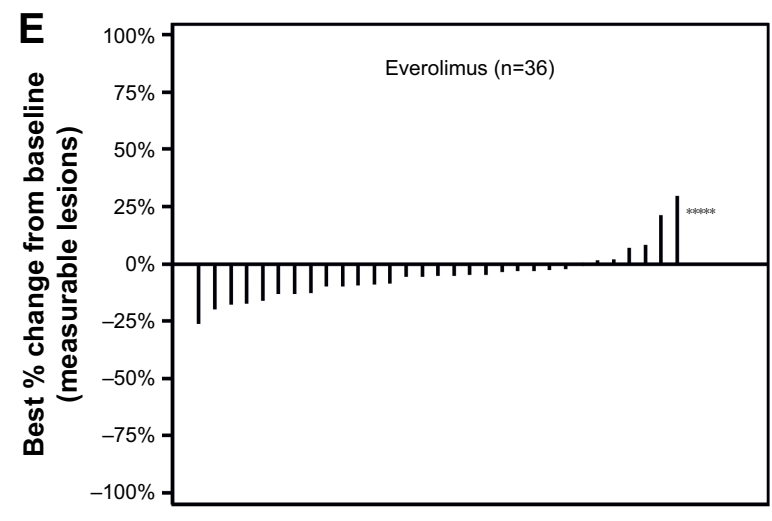

Decrease in best percentage change from baseline

Increase/zero change in best percentage change from baseline

* indicates $\%$ change in target lesion contradicted by overall lesion response = PD $13.9 \%$

Patients for whom the best $\%$ change in target lesions was not available and patients for whom the best $\%$ change in target lesions was contradicted by overall lesion response of unknown were excluded from the analysis, percentages above use $n$ as denominator.
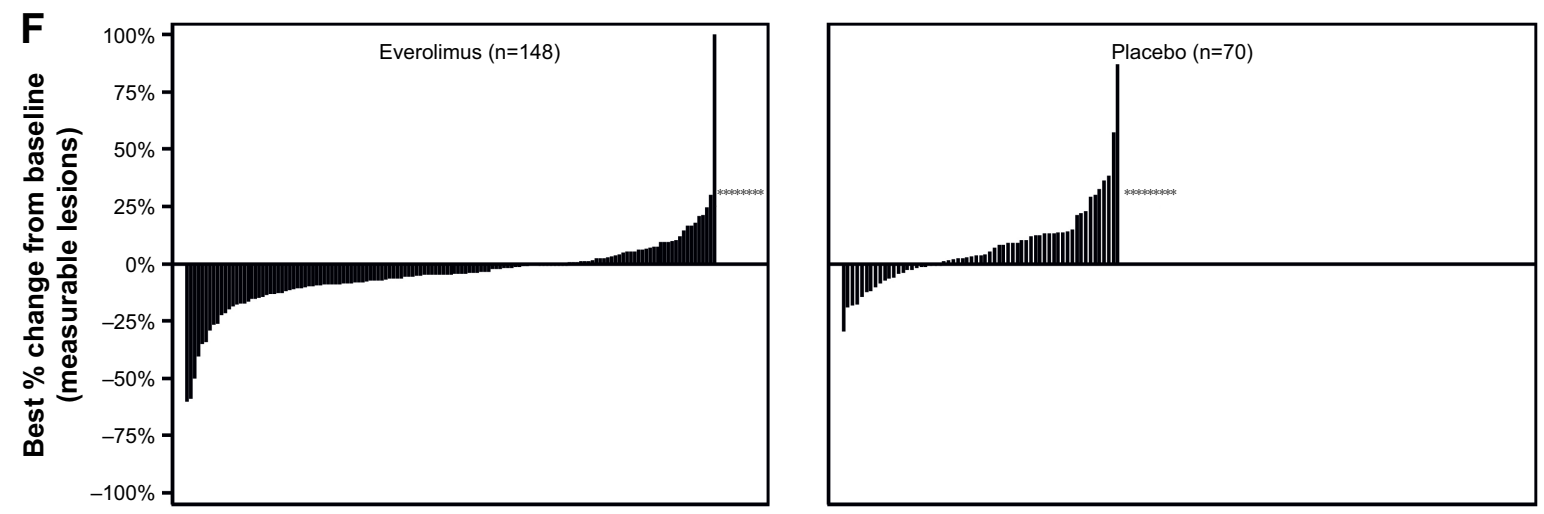

Decrease in best percentage change from baseline

Everolimus Placebo

Increase/zero change in best percentage change from baseline

$62.8 \% \quad 27.1 \%$

* indicates $\%$ change in target lesion contradicted by overall lesion response = PD $6.1 \% \quad 12.9 \%$

Patients for whom the best $\%$ change in target lesions was not available and patients for whom the best $\%$ change in target lesions was contradicted by overall lesion response of unknown were excluded from the analysis, percentages above use $\mathrm{n}$ as denominator.

Figure 2 Percentage change from baseline in size of target lesion, central review (full analysis set)

Notes: The plot shows the best percentage change from baseline in the size of the target lesion (ie, the best response in each patient) in the everolimus arm (left) and placebo arm (right) in the patients who received (A) prior SSA, (B) no prior SSA, (C) prior chemotherapy, (D) no prior chemotherapy, (E) prior radiotherapy, and (F) no prior radiotherapy.

Abbreviations: PD, progressive disease; SSA, somatostatin analogs. 


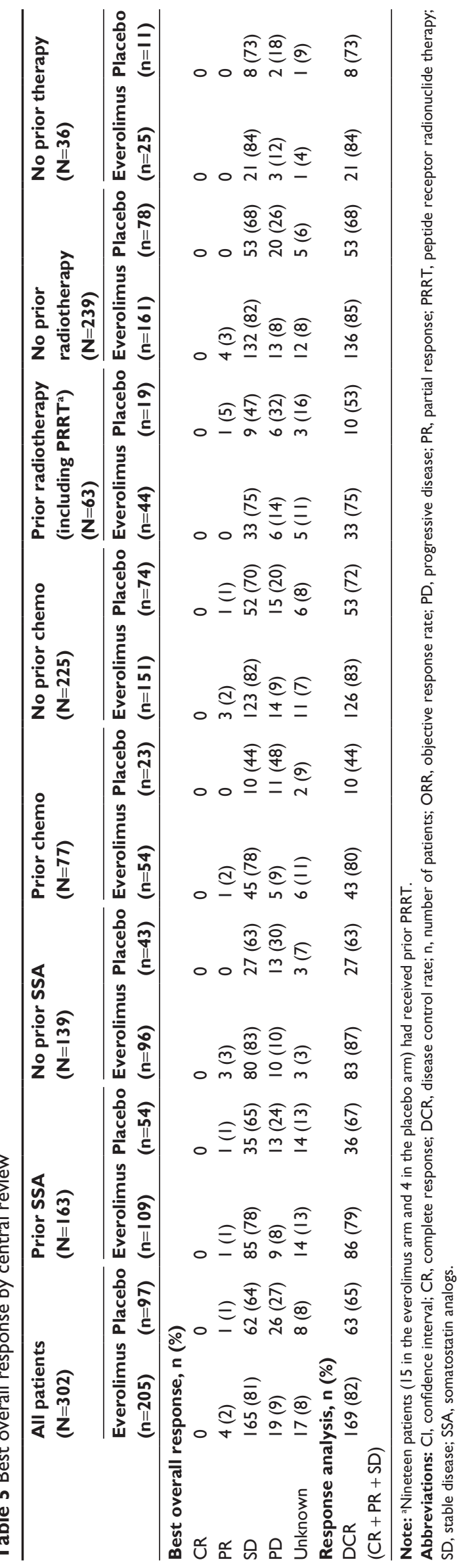

arm (Table 7). Most reported AEs were grade 1 or 2 . The most common drug-related AEs occurring with a frequency $\geq 10 \%$ are listed in Table 6 and included stomatitis, diarrhea, fatigue, infections, rash, and peripheral edema.

\section{Discussion}

Primary results of the RADIANT-4 study reported a statistically significant prolongation of median PFS by 7.1 months with everolimus compared with placebo (HR, $0.48 ; P<0.00001)$ and a $52 \%$ reduction of risk in PFS in patients with advanced, well-differentiated, progressive, nonfunctional NET of lung or GI origin. ${ }^{21}$ In this post hoc exploratory analysis of RADIANT-4 study, we observed a consistent benefit in PFS among patients receiving everolimus compared with placebo irrespective of the use of prior therapies. Everolimus improved the median PFS by 5.8 months to a total of 8 months and contributed to a $40 \%-65 \%$ reduction in relative risk of disease progression or death compared with placebo in subgroups of patients receiving different prior therapies. Everolimus, used in second-line treatment, substantially prolonged the median PFS by 9.4 months in patients who received only prior SSA.

Recent scientific advancements and results from several pivotal clinical trials have transformed our understanding of NET and have changed the treatment paradigm. As the number of available treatment options is increasing for patients with advanced NET, it will become of critical importance to select the treatment based on multiple factors. In addition, since most patients will experience disease progression at some point, an important consideration will be the optimal treatment sequence for these patients, which is currently unknown.

Current evidence-based treatment options for NET include SSA, the mTOR inhibitor everolimus, the multiple tyrosine kinase inhibitor (TKI) sunitinib and PRRT with ${ }^{177} \mathrm{Lu}$-Dotatate. SSA have been an established treatment option since 1980 for effective management of carcinoid syndrome in functional NET. More recently, in 2 placebocontrolled Phase III trials, SSA have also demonstrated antiproliferative activity in patients with low-grade (grade 1) midgut $\mathrm{NET}^{10}$ and in patients with low- to intermediategrade $(\mathrm{Ki}-67<10 \%)$ enteropancreatic NET. ${ }^{9}$ Although SSA were not investigated in gastric or lung NET and their effect remains unclear, SSA use in the absence of any approved drugs could be justified if the tumor is of low grade and expresses the somatostatin receptors (SSTR). ${ }^{24}$ In addition, SSA have also demonstrated a long-term favorable safety profile, and hence, may qualify as a first-line therapy in different types of NET. $9,10,25$ 
Table 6 Drug-related adverse events reported by $\geq 10 \%$ of the patients

\begin{tabular}{|c|c|c|c|c|c|c|c|c|c|c|c|c|}
\hline \multirow[t]{3}{*}{ Preferred term } & \multicolumn{4}{|c|}{ All patients } & \multicolumn{4}{|c|}{ Prior SSA } & \multicolumn{4}{|c|}{ No prior SSA } \\
\hline & \multicolumn{2}{|c|}{$\begin{array}{l}\text { Everolimus } \\
(\mathrm{n}=202)\end{array}$} & \multicolumn{2}{|c|}{$\begin{array}{l}\text { Placebo } \\
(n=98)\end{array}$} & \multicolumn{2}{|c|}{$\begin{array}{l}\text { Everolimus } \\
(n=107)\end{array}$} & \multicolumn{2}{|c|}{$\begin{array}{l}\text { Placebo } \\
(n=55)\end{array}$} & \multicolumn{2}{|c|}{$\begin{array}{l}\text { Everolimus } \\
(\mathrm{n}=95)\end{array}$} & \multicolumn{2}{|l|}{$\begin{array}{l}\text { Placebo } \\
(n=43)\end{array}$} \\
\hline & $\begin{array}{l}\text { All } \\
\text { grades }\end{array}$ & $\begin{array}{l}\text { Grade } \\
3 \text { or } 4\end{array}$ & $\begin{array}{l}\text { All } \\
\text { grades }\end{array}$ & $\begin{array}{l}\text { Grade } \\
3 \text { or } 4\end{array}$ & $\begin{array}{l}\text { All } \\
\text { grades }\end{array}$ & $\begin{array}{l}\text { Grade } \\
3 \text { or } 4\end{array}$ & $\begin{array}{l}\text { All } \\
\text { grades }\end{array}$ & $\begin{array}{l}\text { Grade } \\
3 \text { or } 4\end{array}$ & $\begin{array}{l}\text { All } \\
\text { grades }\end{array}$ & $\begin{array}{l}\text { Grade } \\
3 \text { or } 4\end{array}$ & $\begin{array}{l}\text { All } \\
\text { grades }\end{array}$ & $\begin{array}{l}\text { Grade } \\
3 \text { or } 4\end{array}$ \\
\hline Stomatitis ${ }^{b}$ & $63 \%$ & $9 \%$ & $19 \%$ & 0 & $65 \%$ & $11 \%$ & $16 \%$ & 0 & $61 \%$ & $6 \%$ & $23 \%$ & 0 \\
\hline Diarrhea & $31 \%$ & $7 \%$ & $16 \%$ & $2 \%$ & $34 \%$ & $8 \%$ & $24 \%$ & $2 \%$ & $28 \%$ & $6 \%$ & $7 \%$ & $2 \%$ \\
\hline Fatigue & $31 \%$ & $3 \%$ & $24 \%$ & $1 \%$ & $27 \%$ & $2 \%$ & $22 \%$ & 0 & $35 \%$ & $5 \%$ & $28 \%$ & $2 \%$ \\
\hline Infections ${ }^{c}$ & $29 \%$ & $7 \%$ & $4 \%$ & 0 & $30 \%$ & $8 \%$ & $2 \%$ & 0 & $28 \%$ & $5 \%$ & $7 \%$ & 0 \\
\hline Rash & $27 \%$ & $1 \%$ & $8 \%$ & 0 & $22 \%$ & 0 & $6 \%$ & 0 & $34 \%$ & $1 \%$ & $12 \%$ & 0 \\
\hline Edema, peripheral & $26 \%$ & $2 \%$ & $4 \%$ & $1 \%$ & $28 \%$ & $3 \%$ & $4 \%$ & $2 \%$ & $23 \%$ & $1 \%$ & $5 \%$ & 0 \\
\hline Nausea & $17 \%$ & $1 \%$ & $10 \%$ & 0 & $20 \%$ & $1 \%$ & $6 \%$ & 0 & $15 \%$ & $2 \%$ & $16 \%$ & 0 \\
\hline Anemia & $16 \%$ & $4 \%$ & $2 \%$ & $1 \%$ & $19 \%$ & $4 \%$ & $4 \%$ & $2 \%$ & $14 \%$ & $4 \%$ & 0 & 0 \\
\hline Decreased appetite & $16 \%$ & $1 \%$ & $6 \%$ & 0 & $12 \%$ & 0 & $2 \%$ & 0 & $6 \%$ & 0 & $5 \%$ & 0 \\
\hline Asthenia & $16 \%$ & $1 \%$ & $5 \%$ & 0 & $16 \%$ & $1 \%$ & $6 \%$ & 0 & $17 \%$ & $2 \%$ & $5 \%$ & 0 \\
\hline Noninfectious pneumonitis ${ }^{d}$ & $16 \%$ & $1 \%$ & $1 \%$ & 0 & $14 \%$ & $2 \%$ & 0 & 0 & $18 \%$ & $1 \%$ & $2 \%$ & 0 \\
\hline Dysgeusia & $15 \%$ & $1 \%$ & $4 \%$ & 0 & $15 \%$ & 0 & $7 \%$ & 0 & $15 \%$ & $1 \%$ & 0 & 0 \\
\hline Cough & $13 \%$ & 0 & $3 \%$ & 0 & $13 \%$ & 0 & $4 \%$ & 0 & $13 \%$ & 0 & $2 \%$ & 0 \\
\hline Pruritus & $13 \%$ & $1 \%$ & $4 \%$ & 0 & $12 \%$ & 0 & $2 \%$ & 0 & $14 \%$ & $1 \%$ & $7 \%$ & 0 \\
\hline Pyrexia & $11 \%$ & $2 \%$ & $5 \%$ & 0 & $9 \%$ & $3 \%$ & $6 \%$ & 0 & $13 \%$ & $1 \%$ & $4 \%$ & 0 \\
\hline Dyspnea & $10 \%$ & $1 \%$ & $4 \%$ & $1 \%$ & $10 \%$ & 0 & $4 \%$ & $2 \%$ & II\% & $2 \%$ & $5 \%$ & 0 \\
\hline Hyperglycemia & $10 \%$ & $3 \%$ & $2 \%$ & 0 & $8 \%$ & 0 & $2 \%$ & 0 & $14 \%$ & $7 \%$ & $2 \%$ & 0 \\
\hline Vomiting & $7 \%$ & $2 \%$ & $4 \%$ & $1 \%$ & $6 \%$ & $2 \%$ & $2 \%$ & $2 \%$ & $8 \%$ & $1 \%$ & $7 \%$ & 0 \\
\hline Dermatitis acneiform & $9 \%$ & 0 & $3 \%$ & 0 & $12 \%$ & 0 & $2 \%$ & 0 & $6 \%$ & 0 & $5 \%$ & 0 \\
\hline Epistaxis & $8 \%$ & $1 \%$ & 0 & 0 & $6 \%$ & 0 & 0 & 0 & $12 \%$ & $2 \%$ & 0 & 0 \\
\hline Weight decreased & $8 \%$ & $1 \%$ & $4 \%$ & 0 & $6 \%$ & 0 & $2 \%$ & 0 & $11 \%$ & $2 \%$ & $7 \%$ & 0 \\
\hline Dry skin & $7 \%$ & 0 & $2 \%$ & 0 & $5 \%$ & 0 & $2 \%$ & 0 & II\% & 0 & $2 \%$ & 0 \\
\hline Dry mouth & $7 \%$ & 0 & $3 \%$ & 0 & $3 \%$ & 0 & $2 \%$ & 0 & $13 \%$ & 0 & $5 \%$ & 0 \\
\hline
\end{tabular}

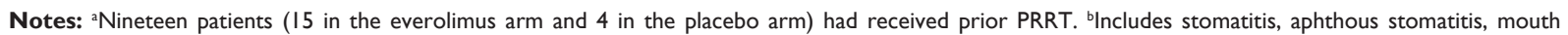
ulceration, and tongue ulceration. Includes all infections. Includes pneumonitis, interstitial lung disease, lung infiltration, and pulmonary fibrosis.

Abbreviations: PRRT, peptide receptor radionuclide therapy; SSA, somatostatin analogs.

Until the availability of novel targeted therapeutic agents in 2011, streptozotocin-based chemotherapy, either in combination with 5-fluorouracil or doxorubicin was an established treatment option for advanced pNET. Different retrospective studies have reported response rates ranging from $25 \%$ to $42 \%$ that support streptozotocin-based chemotherapy activity in the era of novel targeted drugs, particularly in grade 2 (G2) progressive pNET with higher tumor burden. ${ }^{11-13}$ Temozolomide-based chemotherapy, either as monotherapy or in combination with capecitabine or bevacizumab is an alternative regimen in pNET based on the data from limited number of retrospective studies with response rates of $30 \%-70 \%{ }^{26}$ There is very little evidence to support the use of chemotherapy in non-pNET. ${ }^{27}$

PRRT utilizing various radionuclides such as ${ }^{111}$ Indium, ${ }^{90} \mathrm{Yttrium}$, and ${ }^{177}$ Lutetium, has been used for 15 years in many and mostly single-center uncontrolled trials in different types of NET; however, recently, in the first randomized controlled Phase III NETTER-1 trial, ${ }^{177} \mathrm{Lu}$-Dotatate in combination with long-acting octreotide demonstrated a significant prolongation of PFS compared with high-dose octreotide $(60 \mathrm{mg} / \mathrm{month})$ in patients with advanced midgut NET. ${ }^{14}$ The expression of SSTR is an essential criterion for the administration of PRRT, and hence, its use remains limited to a selected subgroup of patients. In addition, there is an increased risk for long-term renal and bone marrow toxicity, as well as a low risk for development of therapyrelated myeloid neoplasms. ${ }^{28,29}$

Currently, approved targeted drugs in NET are sunitinib and everolimus. Everolimus has been more extensively studied in NET and has demonstrated activity across a broad range of NET subtypes from lung to the rectum. ${ }^{20,21}$ Sunitinib is an approved therapy in progressive pNET.${ }^{30}$ Despite some efficacy of novel TKIs (pazopanib, axitinib, cabozantinib) reported in Phase II trials, there is no definite evidence of efficacy of TKIs in NET of non-pancreatic origin. ${ }^{31}$

The safety and tolerability of everolimus in this present subgroup analysis are consistent with the overall RADIANT-4 study population. The most frequent AEs reported with everolimus were grade 1 to 2 in severity and included stomatitis, diarrhea, fatigue, infections, rash, and peripheral edema. No new safety signals were observed 


\begin{tabular}{|c|c|c|c|c|c|c|c|c|c|c|c|c|c|c|c|}
\hline \multicolumn{4}{|c|}{ Prior chemotherapy } & \multicolumn{4}{|c|}{ No prior chemotherapy } & \multicolumn{4}{|c|}{$\begin{array}{l}\text { Prior radiotherapy (including } \\
\text { PRRT }^{\mathrm{a}} \text { ) }\end{array}$} & \multicolumn{4}{|c|}{ No prior radiotherapy } \\
\hline \multicolumn{2}{|c|}{$\begin{array}{l}\text { Everolimus } \\
(n=53)\end{array}$} & \multicolumn{2}{|c|}{$\begin{array}{l}\text { Placebo } \\
(n=23)\end{array}$} & \multicolumn{2}{|c|}{$\begin{array}{l}\text { Everolimus } \\
(n=149)\end{array}$} & \multicolumn{2}{|c|}{$\begin{array}{l}\text { Placebo } \\
(n=75)\end{array}$} & \multicolumn{2}{|c|}{$\begin{array}{l}\text { Everolimus } \\
(\mathrm{n}=44)\end{array}$} & \multicolumn{2}{|c|}{$\begin{array}{l}\text { Placebo } \\
(n=19)\end{array}$} & \multicolumn{2}{|c|}{$\begin{array}{l}\text { Everolimus } \\
(n=158)\end{array}$} & \multicolumn{2}{|l|}{$\begin{array}{l}\text { Placebo } \\
(n=79)\end{array}$} \\
\hline $\begin{array}{l}\text { All } \\
\text { grades }\end{array}$ & $\begin{array}{l}\text { Grade } \\
3 \text { or } 4\end{array}$ & $\begin{array}{l}\text { All } \\
\text { grades }\end{array}$ & $\begin{array}{l}\text { Grade } \\
3 \text { or } 4\end{array}$ & $\begin{array}{l}\text { All } \\
\text { grades }\end{array}$ & $\begin{array}{l}\text { Grade } \\
3 \text { or } 4\end{array}$ & $\begin{array}{l}\text { All } \\
\text { grades }\end{array}$ & $\begin{array}{l}\text { Grade } \\
3 \text { or } 4\end{array}$ & $\begin{array}{l}\text { All } \\
\text { grades }\end{array}$ & $\begin{array}{l}\text { Grade } \\
3 \text { or } 4\end{array}$ & $\begin{array}{l}\text { All } \\
\text { grades }\end{array}$ & $\begin{array}{l}\text { Grade } \\
3 \text { or } 4\end{array}$ & $\begin{array}{l}\text { All } \\
\text { grades }\end{array}$ & $\begin{array}{l}\text { Grade } \\
3 \text { or } 4\end{array}$ & $\begin{array}{l}\text { All } \\
\text { grades }\end{array}$ & $\begin{array}{l}\text { Grade } \\
3 \text { or } 4\end{array}$ \\
\hline $64 \%$ & $11 \%$ & $13 \%$ & 0 & $62 \%$ & $8 \%$ & $21 \%$ & 0 & $59 \%$ & $16 \%$ & $5 \%$ & 0 & $64 \%$ & $7 \%$ & $23 \%$ & 0 \\
\hline $24 \%$ & $6 \%$ & 0 & 0 & $34 \%$ & $8 \%$ & $21 \%$ & $3 \%$ & $27 \%$ & $2 \%$ & $11 \%$ & 0 & $32 \%$ & $9 \%$ & $18 \%$ & $3 \%$ \\
\hline $32 \%$ & $2 \%$ & $22 \%$ & 0 & $30 \%$ & $4 \%$ & $25 \%$ & $1 \%$ & $30 \%$ & $2 \%$ & $26 \%$ & 0 & $31 \%$ & $4 \%$ & $24 \%$ & $1 \%$ \\
\hline $28 \%$ & $9 \%$ & $4 \%$ & 0 & $29 \%$ & $6 \%$ & $4 \%$ & 0 & $32 \%$ & $9 \%$ & 0 & 0 & $29 \%$ & $6 \%$ & $5 \%$ & 0 \\
\hline $24 \%$ & 0 & $4 \%$ & 0 & $28 \%$ & $1 \%$ & $9 \%$ & 0 & $30 \%$ & 0 & 0 & 0 & $27 \%$ & $1 \%$ & $10 \%$ & 0 \\
\hline $19 \%$ & 0 & 0 & 0 & $28 \%$ & $3 \%$ & $5 \%$ & $1 \%$ & $30 \%$ & $7 \%$ & 0 & 0 & $25 \%$ & $1 \%$ & $5 \%$ & $1 \%$ \\
\hline $21 \%$ & $4 \%$ & $4 \%$ & 0 & $16 \%$ & $1 \%$ & $12 \%$ & 0 & $23 \%$ & 0 & $5 \%$ & 0 & $16 \%$ & $2 \%$ & $11 \%$ & 0 \\
\hline $21 \%$ & $7 \%$ & $4 \%$ & $4 \%$ & $15 \%$ & $3 \%$ & I\% & 0 & $21 \%$ & $2 \%$ & 0 & 0 & $15 \%$ & $4 \%$ & $3 \%$ & $1 \%$ \\
\hline $17 \%$ & 0 & 0 & 0 & $15 \%$ & $1 \%$ & $8 \%$ & 0 & $23 \%$ & 0 & 0 & 0 & $14 \%$ & I\% & $8 \%$ & 0 \\
\hline $28 \%$ & $4 \%$ & 0 & 0 & $12 \%$ & $1 \%$ & $7 \%$ & 0 & $18 \%$ & 0 & 0 & 0 & $16 \%$ & $2 \%$ & $6 \%$ & 0 \\
\hline $15 \%$ & $2 \%$ & 0 & 0 & $16 \%$ & $1 \%$ & 0 & 0 & $16 \%$ & $5 \%$ & 0 & 0 & $16 \%$ & I\% & $1 \%$ & 0 \\
\hline $15 \%$ & 0 & 0 & 0 & $15 \%$ & $1 \%$ & $5 \%$ & 0 & $9 \%$ & 0 & 0 & 0 & $17 \%$ & I\% & $5 \%$ & 0 \\
\hline $15 \%$ & 0 & 0 & 0 & $12 \%$ & 0 & $4 \%$ & 0 & $16 \%$ & 0 & $5 \%$ & 0 & $12 \%$ & 0 & $3 \%$ & 0 \\
\hline $13 \%$ & $2 \%$ & 0 & 0 & $13 \%$ & 0 & $5 \%$ & 0 & $7 \%$ & 0 & $5 \%$ & 0 & $15 \%$ & $1 \%$ & $4 \%$ & 0 \\
\hline $15 \%$ & $2 \%$ & 0 & 0 & $15 \%$ & $1 \%$ & $5 \%$ & 0 & $9 \%$ & 0 & 0 & 0 & $11 \%$ & $3 \%$ & $6 \%$ & 0 \\
\hline $6 \%$ & 0 & 0 & 0 & $12 \%$ & $1 \%$ & $5 \%$ & $1 \%$ & $23 \%$ & 0 & $5 \%$ & 0 & $7 \%$ & $1 \%$ & $4 \%$ & $1 \%$ \\
\hline $15 \%$ & $2 \%$ & $4 \%$ & 0 & $9 \%$ & $2 \%$ & $7 \%$ & 0 & $7 \%$ & 0 & 0 & 0 & $11 \%$ & $4 \%$ & $3 \%$ & 0 \\
\hline $11 \%$ & $4 \%$ & $9 \%$ & 0 & $5 \%$ & $1 \%$ & $3 \%$ & $1 \%$ & $7 \%$ & 0 & $5 \%$ & 0 & $7 \%$ & $2 \%$ & $4 \%$ & $1 \%$ \\
\hline $2 \%$ & 0 & 0 & 0 & $12 \%$ & 0 & $4 \%$ & 0 & $7 \%$ & 0 & 0 & 0 & $10 \%$ & 0 & $4 \%$ & 0 \\
\hline $9 \%$ & $2 \%$ & 0 & 0 & $8 \%$ & 0 & 0 & 0 & $9 \%$ & $2 \%$ & 0 & 0 & $8 \%$ & 0 & 0 & 0 \\
\hline $8 \%$ & $2 \%$ & $4 \%$ & 0 & $8 \%$ & $1 \%$ & $4 \%$ & 0 & $11 \%$ & 0 & $5 \%$ & 0 & $7 \%$ & I\% & $4 \%$ & 0 \\
\hline $4 \%$ & 0 & 0 & 0 & $9 \%$ & 0 & $3 \%$ & 0 & $7 \%$ & 0 & 0 & 0 & $8 \%$ & 0 & $3 \%$ & 0 \\
\hline $8 \%$ & 0 & 0 & 0 & $7 \%$ & 0 & $4 \%$ & 0 & $9 \%$ & 0 & 0 & 0 & $7 \%$ & 0 & $4 \%$ & 0 \\
\hline
\end{tabular}

that would preclude its use in patients who received specific prior therapies and most of the everolimus-related AEs were manageable through dose modification or interruption without altering the duration of treatment. As suggested by Berardi et al in a small, retrospective study of 116 patients, cumulative dose and dose intensity of everolimus are prognostic factors for efficacy, and hence, everolimus treatment should be continued in patients who are responding to everolimus despite delays or treatment interruptions. ${ }^{32}$ A population-based, retrospective, multicenter study from Italy suggested that everolimus use after PRRT and/or cytotoxic chemotherapy may increase the overall toxicity of everolimus. ${ }^{33}$ In this analysis, the greater incidence of grade 3 to 4 neutropenia, noninfectious pneumonitis, edema, and thrombocytopenia reported in the prior PRRT subgroup of this study may be related to prior use of PRRT. In general, the safety profile of everolimus in this analysis was comparable, regardless of specific prior therapies, including PRRT (although the numbers of patients who received prior PRRT were very small $[\mathrm{n}=15]$ ) and had a similar safety profile to a smaller retrospective study from the Netherlands. ${ }^{34}$
It is important to note several limitations of the present analysis, including the small sample size for some of the subgroups, the imbalanced patient numbers between treatment groups, and the retrospective nature of the evaluation. However, consistent improvements in PFS with everolimus were observed across all subgroups similar to primary results of the RADIANT-4 study. As an exploratory analysis, it is not powered to support conclusions regarding treatment outcomes, and hence, the results should be considered with caution.

Currently, due to the lack of definite treatment predictors, treatment decisions are made by clinical judgment and pathological criteria. Newer evidence-based treatment strategies have changed the treatment landscape for NET, but the ideal treatment sequence that can be provided to patients remains unknown.

\section{Conclusion}

Given the growing number of therapeutic options becoming available, it is important to select therapies based on treatment goals individualized to the patient. The present RADIANT-4 subanalysis demonstrates that everolimus improved outcomes for patients with advanced, progressive, nonfunctional lung 
Table 7 Drug-related adverse events reported by $\geq 10 \%$ of the patients with respect to prior PRRT

\begin{tabular}{|c|c|c|c|c|c|c|c|c|c|c|c|c|}
\hline \multirow[t]{3}{*}{ Preferred term } & \multicolumn{4}{|c|}{ All patients } & \multicolumn{4}{|c|}{ Prior PRRT } & \multicolumn{4}{|c|}{ No prior PRRT } \\
\hline & \multicolumn{2}{|c|}{$\begin{array}{l}\text { Everolimus } \\
(\mathrm{n}=\mathbf{2 0 2})\end{array}$} & \multicolumn{2}{|c|}{$\begin{array}{l}\text { Placebo } \\
(n=98)\end{array}$} & \multicolumn{2}{|c|}{$\begin{array}{l}\text { Everolimus } \\
(n=15)\end{array}$} & \multicolumn{2}{|c|}{$\begin{array}{l}\text { Placebo } \\
(n=4)\end{array}$} & \multicolumn{2}{|c|}{$\begin{array}{l}\text { Everolimus } \\
(n=187)\end{array}$} & \multicolumn{2}{|c|}{$\begin{array}{l}\text { Placebo } \\
(n=94)\end{array}$} \\
\hline & $\begin{array}{l}\text { All } \\
\text { grades }\end{array}$ & $\begin{array}{l}\text { Grade } \\
3 \text { or } 4\end{array}$ & $\begin{array}{l}\text { All } \\
\text { grades }\end{array}$ & $\begin{array}{l}\text { Grade } \\
3 \text { or } 4\end{array}$ & $\begin{array}{l}\text { All } \\
\text { grades }\end{array}$ & $\begin{array}{l}\text { Grade } \\
3 \text { or } 4\end{array}$ & $\begin{array}{l}\text { All } \\
\text { grades }\end{array}$ & $\begin{array}{l}\text { Grade } \\
3 \text { or } 4\end{array}$ & $\begin{array}{l}\text { All } \\
\text { grades }\end{array}$ & $\begin{array}{l}\text { Grade } \\
3 \text { or } 4\end{array}$ & $\begin{array}{l}\text { All } \\
\text { grades }\end{array}$ & $\begin{array}{l}\text { Grade } \\
3 \text { or } 4\end{array}$ \\
\hline Stomatitis ${ }^{a}$ & $63 \%$ & $9 \%$ & $19 \%$ & 0 & $60 \%$ & $13 \%$ & $25 \%$ & 0 & $63 \%$ & $9 \%$ & $19 \%$ & 0 \\
\hline Diarrhea & $31 \%$ & $7 \%$ & $16 \%$ & $2 \%$ & $27 \%$ & 0 & 0 & 0 & $32 \%$ & $8 \%$ & $17 \%$ & $2 \%$ \\
\hline Fatigue & $31 \%$ & $3 \%$ & $24 \%$ & $1 \%$ & $13 \%$ & 0 & $25 \%$ & 0 & $32 \%$ & $4 \%$ & $25 \%$ & $1 \%$ \\
\hline Infections ${ }^{\mathrm{b}}$ & $29 \%$ & $7 \%$ & $4 \%$ & 0 & $27 \%$ & $7 \%$ & 0 & 0 & $29 \%$ & $7 \%$ & $4 \%$ & 0 \\
\hline Rash & $27 \%$ & $1 \%$ & $8 \%$ & 0 & $13 \%$ & 0 & 0 & 0 & $28 \%$ & $1 \%$ & $9 \%$ & 0 \\
\hline Edema, peripheral & $26 \%$ & $2 \%$ & $4 \%$ & $1 \%$ & $33 \%$ & $7 \%$ & 0 & 0 & $25 \%$ & $2 \%$ & $4 \%$ & $1 \%$ \\
\hline Nausea & $17 \%$ & $1 \%$ & $10 \%$ & 0 & $20 \%$ & 0 & 0 & 0 & $17 \%$ & $2 \%$ & $11 \%$ & 0 \\
\hline Anemia & $16 \%$ & $4 \%$ & $2 \%$ & $1 \%$ & $20 \%$ & 0 & 0 & 0 & $16 \%$ & $4 \%$ & $2 \%$ & $1 \%$ \\
\hline Decreased appetite & $16 \%$ & $1 \%$ & $6 \%$ & 0 & $13 \%$ & 0 & 0 & 0 & $16 \%$ & $1 \%$ & $6 \%$ & 0 \\
\hline Asthenia & $16 \%$ & $1 \%$ & $5 \%$ & 0 & $33 \%$ & 0 & 0 & 0 & $15 \%$ & $2 \%$ & $5 \%$ & 0 \\
\hline Noninfectious pneumonitis ${ }^{c}$ & $16 \%$ & $1 \%$ & $1 \%$ & 0 & $20 \%$ & $7 \%$ & 0 & 0 & $16 \%$ & $1 \%$ & $1 \%$ & 0 \\
\hline Dysgeusia & $15 \%$ & $1 \%$ & $4 \%$ & 0 & $13 \%$ & 0 & 0 & 0 & $15 \%$ & $1 \%$ & $4 \%$ & 0 \\
\hline Cough & $13 \%$ & 0 & $3 \%$ & 0 & $20 \%$ & 0 & 0 & 0 & $12 \%$ & 0 & $3 \%$ & 0 \\
\hline Pruritus & $13 \%$ & $1 \%$ & $4 \%$ & 0 & $7 \%$ & 0 & 0 & 0 & $13 \%$ & $1 \%$ & $4 \%$ & 0 \\
\hline Pyrexia & $11 \%$ & $2 \%$ & $5 \%$ & 0 & $13 \%$ & 0 & 0 & 0 & $11 \%$ & $2 \%$ & $5 \%$ & 0 \\
\hline Dyspnea & $10 \%$ & $1 \%$ & $4 \%$ & $1 \%$ & $20 \%$ & 0 & $25 \%$ & 0 & $10 \%$ & $1 \%$ & $3 \%$ & $1 \%$ \\
\hline Hyperglycemia & $10 \%$ & $3 \%$ & $2 \%$ & 0 & NA & NA & NA & NA & $11 \%$ & $4 \%$ & $2 \%$ & 0 \\
\hline Headache & $7 \%$ & 0 & $6 \%$ & 0 & $13 \%$ & 0 & 0 & 0 & $6 \%$ & 0 & $6 \%$ & 0 \\
\hline Hypercholesterolemia & $5 \%$ & 0 & $1 \%$ & 0 & $13 \%$ & 0 & 0 & 0 & $5 \%$ & 0 & $1 \%$ & 0 \\
\hline Neutropenia & $2 \%$ & $2 \%$ & $1 \%$ & 0 & $13 \%$ & $13 \%$ & 0 & 0 & $1 \%$ & $1 \%$ & $1 \%$ & 0 \\
\hline Thrombocytopenia & $4 \%$ & $1 \%$ & $1 \%$ & 0 & $13 \%$ & $7 \%$ & 0 & 0 & $3 \%$ & $1 \%$ & $1 \%$ & 0 \\
\hline
\end{tabular}

Notes: ${ }^{a}$ Includes stomatitis, aphthous stomatitis, mouth ulceration, and tongue ulceration. ${ }^{b}$ Includes all infections. Includes pneumonitis, interstitial lung disease, lung infiltration, and pulmonary fibrosis.

Abbreviation: PRRT, peptide receptor radionuclide therapy.

or GI NET regardless of the use of prior therapies and suggests the potential for its use in treatment-naive and previously treated patients. The safety profile of everolimus was not impacted by the use of prior therapies and was similar to that reported for the overall analysis population.

\section{Acknowledgments}

We thank all the investigators and their patients for their participation in the study. We thank Rohit Kachhadiya, M. Pharm, (Novartis Healthcare Pvt. Ltd.) for providing medical editorial assistance with this manuscript. This study was funded by Novartis Pharmaceuticals Corporation. This study was presented in part at the European Neuroendocrine Tumor Society (ENETS) conference, Barcelona, Spain; March 9 to $11,2016$.

\section{Author contributions}

Study concept and design: James C Yao, Nicola Fazio, Simron Singh, Jonathan Strosberg, Fabian Herbst, and Marianne E Pavel. Provision of study material or patients: Roberto Buzzoni, Carlo Carnaghi, Jonathan Strosberg, Nicola Fazio, Simron Singh, Marianne E Pavel, Edward M Wolin, Juan W Valle, Do-Youn Oh, James C Yao, and Rodney Pommier. Statistical analysis: Antonia Ridolfi. All authors contributed toward data interpretations, drafting and critically revising the paper, gave final approval of the version to be published, and agree to be accountable for all aspects of the work.

\section{Disclosure}

The authors report the following types of declarations of interest: consultant/advisory relationship (C/A), employment (E), honoraria received $(\mathrm{H})$, intellectual property rights/inventor/patent holder (IP), leadership position (L), ownership interest (OI), research funding (RF), speaker's bureau (SB), and travel and accommodation expenses (TAE). Roberto Buzzoni: Italfarmaco, Novartis, Otsuka (RF); Ipsen, Italfarmaco, Novartis (TAE); Jonathan Strosberg: Novartis (H); Ipsen, Lexicon, Novartis (C/A); Novartis, Pfizer (RF); Bayer, Genentech (SB); Nicola Fazio: Ipsen, Novartis (H); Ipsen, Lexicon, Novartis, Italfarmaco (C/A); Novartis (RF); Ipsen, Novartis (TAE); Simron Singh: Novartis (H, C/A, TAE, RF); Fabian Herbst: Novartis (E, OI); Antonia Ridolfi: Novartis (E); Marianne E Pavel: Ipsen, Lexicon, Novartis, Pfizer (H); Ipsen, Lexicon, Novartis, Pfizer (C/A); Novartis (RF); Ipsen, Novartis (TAE); Edward M Wolin: Celgene, Ipsen, Novartis (C/A); Juan W Valle: Novartis (H, C/A, RF); James C Yao: Ipsen, Lexicon, Novartis (C/A); Novartis (RF); Rodney Pommier: Novartis, Pfizer, Ipsen, 
Lexicon (C/A); Novartis, Ipsen, Lexicon (TAE). The other authors report no conflicts of interest in this work.

\section{References}

1. Maggard MA, O'Connell JB, Ko CY. Updated population-based review of carcinoid tumors. Ann Surg. 2004;240(1):117-122.

2. Yao JC, Hassan M, Phan A, et al. One hundred years after "carcinoid": epidemiology of and prognostic factors for neuroendocrine tumors in 35,825 cases in the United States. $J$ Clin Oncol. 2008;26(18): 3063-3072.

3. Shen C, Dasari A, Zhao B, et al. Incidence and prevalence of neuroendocrine tumors in the United States 1973-2012. abstr 121 presented at NANETS 2016.

4. Vinik AI, Woltering EA, Warner RR, et al. NANETS consensus guidelines for the diagnosis of neuroendocrine tumor. Pancreas. 2010; 39(6):713-734.

5. Kunz PL, Reidy-Lagunes D, Anthony LB, et al. Consensus guidelines for the management and treatment of neuroendocrine tumors. Pancreas. 2013;42(4):557-577.

6. Wong MH, Chan DL, Lee A, et al. Systematic review and meta-analysis on the role of chemotherapy in advanced and metastatic neuroendocrine tumor (NET). PLoS One. 2016;11(6):e0158140.

7. Bajetta E, Procopio G, Catena L, et al. Lanreotide Autogel every 6 weeks compared with Lanreotide microparticles every 3 weeks in patients with well differentiated neuroendocrine tumors: a phase III study. Cancer. 2006;107(10):2474-2481.

8. Janson ET, Westlin JE, Eriksson B, Ahlstrom H, Nilsson S, Oberg K. [111In-DTPA-D-Phe1] octreotide scintigraphy in patients with carcinoid tumours: the predictive value for somatostatin analogue treatment. Eur J Endocrinol. 1994;131(6):577-581.

9. Caplin ME, Pavel M, Cwikla JB, et al. Lanreotide in metastatic enteropancreatic neuroendocrine tumors. N Engl J Med. 2014;371(3): 224-233.

10. Rinke A, Muller HH, Schade-Brittinger C, et al. Placebo-controlled, double-blind, prospective, randomized study on the effect of octreotide LAR in the control of tumor growth in patients with metastatic neuroendocrine midgut tumors: a report from the PROMID Study Group. J Clin Oncol. 2009;27(28):4656-4663.

11. Clewemar Antonodimitrakis P, Sundin A, Wassberg C, Granberg D, Skogseid B, Eriksson B. Streptozocin and 5-fluorouracil for the treatment of pancreatic neuroendocrine tumors: efficacy, prognostic factors and toxicity. Neuroendocrinology. 2016;103(3-4): 345-353.

12. Dilz LM, Denecke T, Steffen IG, et al. Streptozocin/5-fluorouracil chemotherapy is associated with durable response in patients with advanced pancreatic neuroendocrine tumours. Eur J Cancer. 2015; 51(10):1253-1262.

13. Krug S, Boch M, Daniel H, et al. Streptozocin-based chemotherapy in patients with advanced neuroendocrine neoplasms-predictive and prognostic markers for treatment stratification. PLoS One. 2015;10(12): e0143822.

14. Strosberg J, El-Haddad G, Wolin E, et al. Phase 3 trial of $177 \mathrm{Lu}-$ Dotatate for midgut neuroendocrine tumors. $N$ Engl J Med. 2017; 376(2):125-135.

15. Castellano D, Bajetta E, Panneerselvam A, et al. Everolimus plus octreotide long-acting repeatable in patients with colorectal neuroendocrine tumors: a subgroup analysis of the phase III RADIANT-2 study. Oncologist. 2013;18(1):46-53.

16. Fazio N, Granberg D, Grossman A, et al. Everolimus plus octreotide long-acting repeatable in patients with advanced lung neuroendocrine tumors: analysis of the phase 3, randomized, placebo-controlled RADIANT-2 study. Chest. 2013;143(4):955-962.
17. Ito T, Okusaka T, Ikeda M, et al. Everolimus for advanced pancreatic neuroendocrine tumours: a subgroup analysis evaluating Japanese patients in the RADIANT-3 trial. Jpn J Clin Oncol. 2012;42(10): 903-911.

18. Pavel ME, Hainsworth JD, Baudin E, et al. Everolimus plus octreotide long-acting repeatable for the treatment of advanced neuroendocrine tumours associated with carcinoid syndrome (RADIANT-2): a randomised, placebo-controlled, phase 3 study. Lancet. 2011; 378(9808):2005-2012.

19. Yao JC, Lombard-Bohas C, Baudin E, et al. Daily oral everolimus activity in patients with metastatic pancreatic neuroendocrine tumors after failure of cytotoxic chemotherapy: a phase II trial. J Clin Oncol. 2010; 28(1):69-76.

20. Yao JC, Shah MH, Ito T, et al. Everolimus for advanced pancreatic neuroendocrine tumors. $N$ Engl J Med. 2011;364(6): 514-523.

21. Yao JC, Fazio N, Singh S, et al. Everolimus for the treatment of advanced, non-functional neuroendocrine tumours of the lung or gastrointestinal tract (RADIANT-4): a randomised, placebo-controlled, phase 3 study. Lancet. 2016;387(10022):968-977.

22. Klimstra DS, Modlin IR, Coppola D, Lloyd RV, Suster S. The pathologic classification of neuroendocrine tumors: a review of nomenclature, grading, and staging systems. Pancreas. 2010;39(6):707-712.

23. Therasse P, Arbuck SG, Eisenhauer EA, et al. New guidelines to evaluate the response to treatment in solid tumors. European Organization for Research and Treatment of Cancer, National Cancer Institute of the United States, National Cancer Institute of Canada. J Natl Cancer Inst. 2000; 92(3):205-216.

24. Pavel M, O'Toole D, Costa F, et al. ENETS consensus guidelines update for the management of distant metastatic disease of intestinal, pancreatic, bronchial neuroendocrine neoplasms (NEN) and NEN of unknown primary site. Neuroendocrinology. 2016;103(2):172-185.

25. Modlin IM, Pavel M, Kidd M, Gustafsson BI. Review article: somatostatin analogues in the treatment of gastroenteropancreatic neuroendocrine (carcinoid) tumours. Aliment Pharmacol Ther. 2010;31(2): 169-188.

26. Koumarianou A, Kaltsas G, Kulke MH, et al. Temozolomide in advanced neuroendocrine neoplasms: pharmacological and clinical aspects. Neuroendocrinology. 2015;101(4):274-288.

27. Lamarca A, Elliott E, Barriuso J, et al. Chemotherapy for advanced non-pancreatic well-differentiated neuroendocrine tumours of the gastrointestinal tract, a systematic review and meta-analysis: a lost cause? Cancer Treat Rev. 2016;44:26-41.

28. Bodei L, Kwekkeboom DJ, Kidd M, Modlin IM, Krenning EP. Radiolabeled somatostatin analogue therapy of gastroenteropancreatic cancer. Semin Nucl Med. 2016;46(3):225-238.

29. Bodei L, Modlin IM, Luster M, et al. Myeloid neoplasms after chemotherapy and PRRT: myth and reality. Endocr Relat Cancer. 2016;23(8):C1-C7.

30. Raymond E, Dahan L, Raoul JL, et al. Sunitinib malate for the treatment of pancreatic neuroendocrine tumors. NEngl J Med. 2011;364(6):501-513.

31. Phan AT, Halperin DM, Chan JA, et al. Pazopanib and depot octreotide in advanced, well-differentiated neuroendocrine tumours: a multicentre, single-group, phase 2 study. Lancet Oncol. 2015;16(6): 695-703.

32. Berardi R, Torniai M, Pusceddu S, et al. Prognostic impact of the cumulative dose and dose intensity of everolimus in patients with pancreatic neuroendocrine tumors. Cancer Med. 2017;6(7):1493-1499.

33. Panzuto F, Rinzivillo M, Fazio N, et al. Real-world study of everolimus in advanced progressive neuroendocrine tumors. Oncologist. 2014;19(9):966-974.

34. Kamp K, Gumz B, Feelders RA, et al. Safety and efficacy of everolimus in gastrointestinal and pancreatic neuroendocrine tumors after (177) Lu-octreotate. Endocr Relat Cancer. 2013;20(6):825-831. 


\section{Supplementary material}

Table SI List of independent ethics committees (IECs) or institutional review boards (IRBs) by study center

\begin{tabular}{|c|c|c|c|}
\hline Center no & Ethics committee or IRB & Department/organization & $\begin{array}{l}\text { City, state/province, postal } \\
\text { code, country }\end{array}$ \\
\hline \multirow[t]{3}{*}{0151} & Ethik-Kommission d. Landes & & Linz, A-4020, Austria \\
\hline & Ethik-Kommission d. Landes & & \\
\hline & Oberoesterreich & & \\
\hline \multirow[t]{2}{*}{0153} & Ethik-Kommission d. Landes & & Linz, A-4020, Austria \\
\hline & Oberosterreich & & \\
\hline 0176 & Commissie Medische Ethiek & & Leuven, 3000, Belgium \\
\hline 0178 & Comité d'Ethique & & Brussels, I200, Belgium \\
\hline 0179 & Ethisch Comité & & Gent, 9000, Belgium \\
\hline 0180 & Comité voor Medische Ethiek & & Edegem, 2650, Belgium \\
\hline 0201 & Ontario Cancer Research Ethics Board & & ON, MSG0A3, Canada \\
\hline 0202 & Ontario Cancer Research Ethics Board & & ON, M5G0A3, Canada \\
\hline 0203 & Capital Health Research Ethics Board & & Halifax, NS, B3H IV7, Canada \\
\hline 0204 & Alberta Cancer Research Committee & & Edmonton, AB, T5J3HI, Canada \\
\hline 0205 & Ontario Cancer Research Ethics Board & & ON, M5G0A3, Canada \\
\hline 0206 & Comite d'éthique de la Recherche & & Montreal, QC, HIT2M4, Canada \\
\hline 0207 & UBC BCCA Research Ethics Board & & Vancouver, BC, V5ZIH5, Canada \\
\hline 0256 & Ethics Committee of Cancer Hospital of CAMS & & Beijing, I0002I, China \\
\hline 0257 & Ethics Committee of Beijing Cancer Hospital & & Beijing, 100142 , China \\
\hline 0258 & Ethics Committee of 307 Hospital of PLA & & Beijing, 100039, China \\
\hline 0260 & Ethics Committee of Peking Union Medical College Hospital & & Beijing, 100032, China \\
\hline 0261 & Ethics Committee of China-Japan Friendship Hospital & & Beijing, 100029, China \\
\hline 0302 & Comite de Etica Investigacion(E) & Cundinamarca & Bogota, Colombia \\
\hline 0321 & LEC Rostov Research Institute of Oncology & & Rostov-na-Donu, 344037, Russia \\
\hline \multirow[t]{2}{*}{0351} & Eticka komise FN a Lékařské & & Olomouc, 77520, Czech Republic \\
\hline & fakulty UP v Olomouci & & \\
\hline \multirow[t]{2}{*}{0353} & Etická komise Všeobecné & & Praha 2, 12808, Czech Republic \\
\hline & fakultní nemocnice $v$ Praze & & \\
\hline \multirow[t]{3}{*}{0354} & Etická komise & & Brno, 65653, Czech Republic \\
\hline & Masarykova Onkologického & & \\
\hline & Ústavu & & \\
\hline \multirow[t]{3}{*}{0401} & Landesamt fur Gesundheit & & Berlin, I0707, Germany \\
\hline & und Soziales Geschaftsstelle & & \\
\hline & der Ethik-Kommission & & \\
\hline \multirow[t]{4}{*}{0402} & Ethik-Kommssion des & & Frankfurt, 60590, Germany \\
\hline & Fachbereichs Goethe- & & \\
\hline & Universitat & & \\
\hline & Universitatsklinikum & & \\
\hline \multirow[t]{4}{*}{0404} & Otto-von-Guericke-Universitat & & Magdeburg, 39120, Germany \\
\hline & Magdeburg Ethik-Kommission & & \\
\hline & an der Medizinischen Fakultat & & \\
\hline & Universitatsklinkum & & \\
\hline \multirow[t]{4}{*}{0406} & Universitaetsklinikum & & Essen Nordrhein-Westfalen, \\
\hline & Essen Medizinische Fakultaet & & 45I47, Germany \\
\hline & der Universitaet Duisburg-Essen & & \\
\hline & Ethik-Kommission & & \\
\hline 0407 & Ethik-Kommission der Medizinischen Hochschule Hannover & & Hannover, 30625, Germany \\
\hline 0408 & Landesarztekammer Rheinland-Pfalz Ethik-Kommission & & Mainz, 55II6, Germany \\
\hline 0409 & Landesaerztekammer Thueringen & Ethik-Kommission & Jena-Maua Thueringen, $0775 \mathrm{I}$, \\
\hline & & & Germany \\
\hline 0451 & National Ethics Committee & & Athens, GR-I5562, Greece \\
\hline 0501 & Etikai Bizottsag; Magyar Honvedseg Egeszsegugyi Kozpont & & Budapest, II34, Hungary \\
\hline \multirow[t]{3}{*}{0502} & Regionalis, Intezmenyi Tudomanyos es Kutatasetikai & & Budapest, I09I, Hungary \\
\hline & Bizottsag; Semmelweis & & \\
\hline & Egyetem & & \\
\hline 0551 & Institute review board of Kyushu University Hospital & & Fukuoka, 8I2-8582, Japan \\
\hline 0552 & Institute review board of National Cancer Center Hospital & & Chuo-ku, Tokyo 104-0045, Japan \\
\hline
\end{tabular}


Table SI (Continued)

\begin{tabular}{|c|c|c|c|}
\hline Center no & Ethics committee or IRB & Department/organization & $\begin{array}{l}\text { City, state/province, postal } \\
\text { code, country }\end{array}$ \\
\hline \multirow[t]{2}{*}{0553} & Institute review board of the Kansai Electric Power & & Osaka, 553-0003, Japan \\
\hline & Hospital & & \\
\hline 0601 & Asan Medical Center Institutional Review Board & & Seoul, 138-736, Republic of Korea \\
\hline 0602 & Samsung Medical Center Institutional Review Board & & Seoul, I35-7|10, Republic of Korea \\
\hline \multirow[t]{2}{*}{0603} & Seoul National University Hospital Institutional Review & & Seoul, I I0-744, Republic of Korea \\
\hline & Board & & \\
\hline \multirow[t]{2}{*}{0604} & The Catholic University of Korea Seoul St Mary's Hospital & & Seoul, I37-70I, Republic of Korea \\
\hline & Institutional Review Board & & \\
\hline 0605 & Severance Hospital Institutional Review Board & & Seoul, 120-752, Republic of Korea \\
\hline \multirow[t]{2}{*}{0626} & Eticka komisia NOU & & Bratislava, NA 833 0I, Slovakia \\
\hline & Bratislava & & (Slovak Republic) \\
\hline \multirow[t]{2}{*}{0651} & Commité d'ethique Commité d'ethique of Hôtel Dieu de & & Beirut, 16-6830, Lebanon \\
\hline & France & & \\
\hline 0653 & Institute review board of American University of Beirut & & Beirut, Lebanon \\
\hline 0671 & METC AVL ziekenhuis & & $\begin{array}{l}\text { Amsterdam, } 1066 \mathrm{CX} \text {, } \\
\text { the Netherlands }\end{array}$ \\
\hline \multirow[t]{2}{*}{0721} & Comitato Etico Dell'irccs Istituto Clinico Humanitas Di & & Rozzano, MI 20089, Italy \\
\hline & Rozzano & & \\
\hline 0722 & Comitato Etico Della Provincia di Modena & & Modena, MO 4I I 24, Italy \\
\hline 0723 & Comitato Etico Degli irccs Istituto Europeo di oncologiae & & Milan, MI 20I4I, Italy \\
\hline \multirow[t]{3}{*}{0724} & Comitato Etico Independente & & Bologna, BO 40I38, Italy \\
\hline & Dell'Azienda Ospedalierouniveritaria & & \\
\hline & Policlinico S. Orsola & & \\
\hline \multirow[t]{2}{*}{0725} & Comitato Etico Dell'Universita' & & Rome, RM 0016I, Italy \\
\hline & Sapienza & & \\
\hline \multirow[t]{2}{*}{0726} & Comitato Etico Dell'Azienda & & Naples, NA 80I3I, Italy \\
\hline & Ospedaliea A. Cardelli Napoli & & \\
\hline \multirow[t]{2}{*}{0727} & Comitato Etico Della Fondazione Irccs Istituto Nazionale & & Milan, MI 20I33, Italy \\
\hline & Dei Tumori Di Milano & & \\
\hline \multirow[t]{2}{*}{0728} & Comitato Etico Dell'Universita' & & Rome, RM 00I68, Italy \\
\hline & Cattolica Del S. Cuore - Policlinico Gemelli, ROMA - & & \\
\hline 0731 & Comitato Etico Della Provincia di Brescia & & Brescia, BS 25I23, Italy \\
\hline \multirow[t]{2}{*}{0734} & Comitato Etico Dell'Azienda Sanitaria Provinciale Di & & Catania, CT 95 I24, Italy \\
\hline & Catania & & \\
\hline \multirow[t]{2}{*}{0736} & Comitato Etico Per La Sperimentazione Clinica Delle & & Verona, VR 37I34, Italy \\
\hline & Province di Verona E Rovigo Presso Aoui Verona & & \\
\hline \multirow[t]{3}{*}{0737} & Comitato Etico Area Vasta Centro, Azienda & & Firenze, FI 50I34, Italy \\
\hline & Ospedalierouniveritaria & & \\
\hline & Careggi Di Firenze & & \\
\hline \multirow[t]{2}{*}{0738} & Comitato Etico Dell'irccs Istituto Per Lo Studio e la Cura & & Napoli, NA 80I3I, Italy \\
\hline & Dei Tumori Fondazione Giovanni Pascale Di Napoli & & \\
\hline 0751 & Office of Research Affairs & Research Centre & Riyadh, II2II, Saudi Arabia \\
\hline \multirow[t]{4}{*}{0761} & Unidad de Soporte al CEIC & Fundació Hospital & Barcelona, 08035, Spain \\
\hline & & Universitari Vall d'Hebron & \\
\hline & & - Institut de Recerca & \\
\hline & & $(\mathrm{VHIR})$ & \\
\hline \multirow[t]{2}{*}{0762} & CEIC Comité de Ética de Investigación Clínica Hospital & Hospital Universitari de & Barcelona, 08907, Spain \\
\hline & Universitari de Bellvitge & Bellvitge Hospitalet de Llobregat & \\
\hline \multirow[t]{2}{*}{0764} & Comité Ético De Investigación Clínica & Hospital Universitario & Seville, 4I009, Spain \\
\hline & & Virgen Macarena & \\
\hline 0781 & Komisja Bioetyczna przy Uniwersytecie & & Poznan, 6I-70I, Poland \\
\hline & Medycznym im. Karola Marcinkowskiego & & \\
\hline & w Poznaniu & & \\
\hline 0783 & Komisja Bioetyczna przy Uniwersytecie & & Poznan, 6I-70I, Poland \\
\hline & Medycznym im. Karola Marcinkowskiego & & \\
\hline & w Poznaniu & & \\
\hline
\end{tabular}


Table SI (Continued)

\begin{tabular}{|c|c|c|c|}
\hline Center no & Ethics committee or IRB & Department/organization & $\begin{array}{l}\text { City, state/province, postal } \\
\text { code, country }\end{array}$ \\
\hline 0801 & $\begin{array}{l}\text { University of the Witwatersrand Human } \\
\text { Research Ethics Committee }\end{array}$ & Medical & Houghton, 204I, South Africa \\
\hline 0826 & NRES Committee North West-Liverpool East & & Manchester, MI 3DZ, UK \\
\hline 0827 & NRES Committee North West-Liverpool East & & Manchester, MI 3DZ, UK \\
\hline 0828 & NRES Committee North West-Liverpool East & & Manchester, MI 3DZ, UK \\
\hline 0829 & NRES Committee North West-Liverpool East & & Manchester, MI 3DZ, UK \\
\hline 0830 & NRES Committee North West-Liverpool East & & Manchester, MI 3DZ, UK \\
\hline 0832 & NRES Committee North West-Liverpool East & & Manchester, MI 3DZ, UK \\
\hline 0851 & Chang Gung Medical Foundation Institutional Review Board & & Taoyuan, 333, Taiwan \\
\hline 0852 & $\begin{array}{l}\text { The Institutional Review Board of Taichung Veterans } \\
\text { General Hospital }\end{array}$ & & Taichung, 40705, Taiwan \\
\hline 0854 & Chang Gung Medical Foundation Institutional Review Board & & Taoyuan, 33378, Taiwan \\
\hline 0855 & $\begin{array}{l}\text { Institutional Review Board, Taipei Veterans General } \\
\text { Hospital }\end{array}$ & & Taipei, II217, Taiwan \\
\hline 0856 & $\begin{array}{l}\text { Research Ethics Committee, National Taiwan University } \\
\text { Hospital }\end{array}$ & & Taipei, I0048, Taiwan \\
\hline 0876 & $\begin{array}{l}\text { Institutional Reveiw Board, Faculty of Medicine, } \\
\text { Chulalongkorn University }\end{array}$ & $\begin{array}{l}\text { Faculty of Medicine, } \\
\text { Chulalongkorn University }\end{array}$ & Bangkok, 10330, Thailand \\
\hline 0877 & Research Ethics Committee 2 & $\begin{array}{l}\text { Faculty of Medicine, Chiang Mai } \\
\text { University }\end{array}$ & Chiang Mai, 50200, Thailand \\
\hline 0901 & UCSD Human Research Protections Program & & La Jolla, CA, 92093-0052, USA \\
\hline 0902 & $\begin{array}{l}\text { University of Texas/MD Anderson Cancer Center } \\
\text { Institutional Review Board }\end{array}$ & & Houston, TX, 77030, USA \\
\hline 0903 & Liberty IRB & & DeLand, FL, 32720, USA \\
\hline 0904 & UT Southwestern Institutional Review Board & & Dallas, TX, 75390-8843, USA \\
\hline 0905 & Biomedical Research Alliance of New York & & Bronx, NY, I I042, USA \\
\hline 0907 & $\begin{array}{l}\text { Cedars Sinai Medical Center Office of Research } \\
\text { Compliance }\end{array}$ & & Los Angeles, CA, 9021I, USA \\
\hline 0908 & OHSU Institutional Review Board & & Portland, OR, 97239, USA \\
\hline 0909 & Western Institutional Review Board & & Olympia, WA, 98502, USA \\
\hline 0910 & IU Health Goshen Hospital Institutional Review Board & & Goshen, IN, 46526, USA \\
\hline 0916 & Institutional Review Board Dana Farber Cancer Institute & & Boston, MA, 02215, USA \\
\hline 0921 & Scripps Institutional Review Board & & La Jolla, CA, 92037, USA \\
\hline 0923 & The University of Chicago Institutional Review Board & & Chicago, IL, 60637, USA \\
\hline 0925 & Western Institutional Review Board, Inc. (WIRB) & & Olympia, WA, 98502-5010, USA \\
\hline 0928 & Vanderbilt University Institutional Review Board & & Nashville, TN, 37232-43I5, USA \\
\hline 0933 & $\begin{array}{l}\text { Memorial Sloan Kettering Cancer Center Institutional } \\
\text { Review Board }\end{array}$ & & New York, NY, I0065, USA \\
\hline 0951 & US Oncology, Inc. Institutional Review Board & & The Woodlands, TX, 77380, USA \\
\hline 0952 & US Oncology, Inc. Institutional Review Board & & The Woodlands, TX, 77380, USA \\
\hline 1051 & $\begin{array}{l}\text { Istanbul University Cerrahpasa Medical Faculty Clinical } \\
\text { Researches Ethical Committee }\end{array}$ & & Istanbul, 34098, Turkey \\
\hline 1052 & $\begin{array}{l}\text { Istanbul University Cerrahpasa Medical Faculty Clinical } \\
\text { Researches Ethical Committee }\end{array}$ & & Istanbul, 34098, Turkey \\
\hline
\end{tabular}

OncoTargets and Therapy

\section{Publish your work in this journal}

OncoTargets and Therapy is an international, peer-reviewed, open access journal focusing on the pathological basis of all cancers, potential targets for therapy and treatment protocols employed to improve the management of cancer patients. The journal also focuses on the impact of management programs and new therapeutic agents and protocols on patient perspectives such as quality of life, adherence and satisfaction. The manuscript management system is completely online and includes a very quick and fair peer-review system, which is all easy to use. Visit http://www.dovepress.com/testimonials.php to read real quotes from published authors. 